

\section{REVIEW OF CONFIGURATION OF THE GREATER MEKONG SUBREGION ECONOMIC CORRIDORS}


(C) 2018 Asian Development Bank 6 ADB Avenue, Mandaluyong City, 1550 Metro Manila, Philippines

Tel +632632 4444; Fax +6326362444

www.adb.org

Some rights reserved. Published in 2018.

ISBN 978-92-9261-046-3 (print), 978-92-9261-047-0 (electronic)

Publication Stock No. TCS179180

DOI: http://dx.doi.org/10.22617/TCS179180

The views expressed in this publication are those of the authors and do not necessarily reflect the views and policies of the Asian Development Bank (ADB) or its Board of Governors or the governments they represent.

ADB does not guarantee the accuracy of the data included in this publication and accepts no responsibility for any consequence of their use. The mention of specific companies or products of manufacturers does not imply that they are endorsed or recommended by ADB in preference to others of a similar nature that are not mentioned.

By making any designation of or reference to a particular territory or geographic area, or by using the term "country" in this document, $A D B$ does not intend to make any judgments as to the legal or other status of any territory or area.

This work is available under the Creative Commons Attribution 3.0 IGO license (CC BY 3.0 IGO)

https://creativecommons.org/licenses/by/3.o/igo/. By using the content of this publication, you agree to be bound by the terms of this license. For attribution, translations, adaptations, and permissions, please read the provisions and terms of use at https://www.adb.org/terms-use\#openaccess.

This CC license does not apply to non-ADB copyright materials in this publication. If the material is attributed to another source, please contact the copyright owner or publisher of that source for permission to reproduce it. $\mathrm{ADB}$ cannot be held liable for any claims that arise as a result of your use of the material.

Please contact pubsmarketing@adb.org if you have questions or comments with respect to content, or if you wish to obtain copyright permission for your intended use that does not fall within these terms, or for permission to use the ADB logo.

Notes:

In this publication, "\$” refers to US dollars.

Corrigenda to ADB publications may be found at http://www.adb.org/publications/corrigenda. 


\section{CONTENTS}

FIGURES AND TABLES

ABBREVIATIONS

II GREATER MEKONG SUBREGION ECONOMIC CORRIDORS 2

III EVOLUTION OF THE GREATER MEKONG SUBREGION CORRIDORS

IV ECONOMIC CORRIDOR REALIGNMENT AND/OR EXTENSION 10

A. Assessment of Corridor Alignment 10

B. Criteria for Realignment and/or Extension 11

C. Proposed Corridor Realignment and/or Extension $\quad 12$

V COMPLEMENTARY MEASURES AND APPROACHES 16

$\begin{array}{ll}\text { VI RECOMMENDATIONS } & 19\end{array}$

APPENDIXES

1 Location of Special Economic Zones in the Greater Mekong Subregion 22

2 Population Distribution along the Greater Mekong Subregion Corridors 23

3 Myanmar: Exports and Imports by Trade Station 24 


\section{FIGURES AND TABLES}

\section{FIGURES}

1 Greater Mekong Subregion Economic Corridors, 2000-2008 5

2 Greater Mekong Subregion Corridor Network in Transport Sector Strategy, 2006-2015 6

3 Present Configuration of East-West Economic Corridor, North-South Economic Corridor, and Southern Economic Corridor

4 Overlay of the Greater Mekong Subregion Economic Corridors on the Greater Mekong Subregion Corridor Network

5 Intercountry Distribution of the Greater Mekong Subregion Economic Corridors

6 Proposed Realignment and/or Extension of the Greater Mekong Subregion Economic Corridors

7 New Configuration of East-West Economic Corridor, North-South Economic Corridor, and Southern Economic Corridor

\section{TABLES}

1 Key Milestones in the Evolution of the Greater Mekong Subregion Corridors

2 Original and Amended Configuration of North-South Economic Corridor and Southern Economic Corridor

3 Proposed Levels of Economic Corridors and Corresponding Focus of Interventions

4 Present Names of the Greater Mekong Subregion Corridors in the Transport Sector Strategy and Strategies and Action Plans for East-West Economic Corridor, North-South Economic Corridor, and Southern Economic Corridor

5 Proposed Names of North-South Economic Corridor and Southern Economic Corridor Subcorridors

6 Sample Application of the Proposed Classification of the Greater Mekong Subregion Economic Corridors 


\section{ABBREVIATIONS}

ADB

PRC

ECF

EU

EWEC

GMS

Lao PDR

NSEC

SAP

SEC

SEZ

TEN-T

TSS

TTF
Asian Development Bank

People's Republic of China

Economic Corridors Forum

European Union

East-West Economic Corridor

Greater Mekong Subregion

Lao People's Democratic Republic

North-South Economic Corridor

strategy and action plan

Southern Economic Corridor

special economic zone

Trans-European Transport Network

Transport Sector Strategy

transport and trade facilitation 


\section{EXECUTIVESUMMARY}

- he Greater Mekong Subregion (GMS) countries adopted the economic corridor approach at the Eighth GMS Ministerial Conference in Manila in 1998 to accelerate subregional development. The East-West Economic Corridor (EWEC), North-South Economic Corridor (NSEC), and Southern Economic Corridor (SEC) were subsequently designated as flagship programs under the Ten-Year GMS Strategic Framework, 2002-2012. Thus, complementary efforts such as trade and transport facilitation, border and corridor towns development, investment promotion, and enterprise development have been largely focused on EWEC, NSEC, and SEC. The development of GMS corridors as economic corridors continued to be at the center of the GMS Program under the succeeding GMS Strategic Framework, 2012-2022.

GMS economic corridors have evolved in three stages. The first stage, from 1992 to 1997, laid the foundations for the development of the corridors. Priority road projects identified during this time served as the backbone of the GMS economic corridors. The second stage, from 1998 to 2007, started with the adoption of the economic corridor approach and the designation of EWEC, NSEC, and SEC as priority corridors for transformation into economic corridors. The third stage, from 2008 onward, formulated the strategies and action plans (SAPs) for EWEC, NSEC, and SEC, and their implementation thereafter.

The need to review the configuration of EWEC, NSEC, and SEC to enhance their contribution to GMS development was first raised at the Fourth Economic Corridors Forum (ECF) held in Mandalay, Myanmar in June 2012. Discussions at the Seventh ECF held in Kunming, Yunnan Province, the People's Republic of China (PRC) in June 2015, and the 20th GMS Ministerial Conference held in Nay Pyi Taw, Myanmar in September 2015, also drew attention to the need for such review. Changes in the configuration of GMS economic corridors respond to the dynamic nature of subregional development. They will help ensure that further investments in GMS economic corridor development are focused on areas with the best potential to become fully functioning economic corridors, thus maximizing their contribution to increased incomes and employment in the subregion.

The present configuration of EWEC, NSEC, and SEC is based on (i) the SAPs for EWEC and NSEC endorsed at the 15th GMS Ministerial Conference in 2009; (ii) the SAP for SEC endorsed at the 16th Ministerial Conference in 2010; and (iii) the decision made at the 17th Ministerial Conference in 2011 to add Dawei, Myanmar to SEC.

The primary considerations for including specific routes as part of EWEC, NSEC, and SEC in the current configuration were their potential to become trade, investment, tourism, and transit corridors, and the presence of significant sections that can be developed into hubs for regional trade, investment, and tourism. In reviewing their configuration, the primary concern is to ensure that: (i) developments arising from the opening up of Myanmar are taken into account; (ii) corridors include and link all GMS capitals and major economic centers; (iii) corridors are connected to key GMS maritime gateways and industrial hubs; and (iv) major trade flows are reflected in the alignment of the corridors.

Based on these requisites, the following glaring gaps need to be addressed through extension and/or realignment of the economic corridors:

- There is relatively limited coverage of the Lao People's Democratic Republic (Lao PDR) and Myanmar in the economic corridors.

- Yangon, Nay Pyi Taw, and Vientiane are not included in any economic corridor.

- Yangon Port is not linked to any economic corridor.

- The principal cross-border trade routes between the PRC and Myanmar; Myanmar and Thailand; and the PRC, the Lao PDR, and Thailand are not reflected in the alignment of the economic corridors. 
To address these gaps, the following changes in the configuration of the GMS economic corridors are proposed:

\section{East-West Economic Corridor}

Include an extension at the western end of EWEC to Yangon-Thilawa using the Myawaddy-Kawkareik-Eindu-Hpa-An-ThatonKyaikto-Payagi-Bago-Yangon-Thilawa route, with a possible extension to Pathein.

- This addresses major omissions in the configuration of GMS economic corridors - the absence of Yangon and Yangon Port, Myanmar's principal gateway port for imports and exports, in any of the corridors.

- The Bangkok-Yangon route through Mae Sot-Myawaddy is the primary trade route between Thailand and Myanmar. The development of this route is of high priority, as trade between the two countries is expected to grow rapidly as a result of the new economic and political situation in Myanmar. Exports and imports through the Mae Sot-Myawaddy border increased threefold during 2013-2015, and in just the first 3 months of 2016 there were already $70 \%$ more exports and imports than during the whole 2015.

- The ongoing projects for the improvement of this route are (i) the Eindu-Kawkareik Road Improvement Project funded by the Asian Development Bank and (ii) the Mae Sot-Myawaddy Border Crossing and Infrastructure Improvements Project financed by the Government of Thailand. Myawaddy is being developed by the Government of Myanmar as a special border economic and industrial zone; and Thilawa, by the Government of Myanmar and the private sector, as a special economic zone.

- The proposed realignment of EWEC links cities with relatively large populations and emerging industrial hubs, and crosses rural areas with good potential to be linked to agricultural value chains. The Pathein-Yangon-Myawaddy section links the two most important agricultural areas of Myanmar-the Ayeyarwady Delta and the East Bago, Mon, and Kayin region.

- Future connection of Pathein to EWEC can also be considered because of Pathein's potentials for the development of agriculture, forestry, and tourism. All critical bridges from Pathein to Yangon already exist.

\section{North-South Economic Corridor}

Include the Kunming-Dali-Ruili-Muse-Mandalay-Nay Pyi Taw-Yangon route in NSEC.

- This is the main trade route between the PRC and Myanmar. Cross-border trade between the two countries at the Muse-Ruili border gate is the largest among all border gates in Myanmar. The Mandalay-Nay Pyi Taw-Yangon route is the main trade corridor within Myanmar.

- The roads along this route, particularly in the northern section that passes through difficult mountainous terrain, require substantial improvement to handle increased traffic. Complementary investments such as development of inland container depots will also be necessary to increase the viability of the corridor. Inclusion of this route in NSEC will sharpen the focus and strengthen efforts to improve infrastructure and promote investment along this corridor.

Add an extension to the Kunming-Dali-Ruili-Muse-Mandalay-Nay Pyi Taw-Yangon route to link Mandalay to Tamu at the border with India, using the Mandalay-Kalewa-Tamu route via Monywa or Shwebo.

- The proposed extension expands the coverage of GMS economic corridors in Myanmar, and recognizes Myanmar's role as a land bridge to South Asia.

- Although cross-border trade between India and Myanmar is small compared with Myanmar's cross-border trade with the PRC and Thailand, the prospects are favorable for increased trade and investment if bottlenecks in infrastructure, border facilities and formalities, and trade financing are addressed.

- The Kunming-Dali-Ruili-Muse-Mandalay-Nay Pyi Taw-Yangon route, especially the Mandalay-Muse-Ruili section, is expected to increase in importance not only as a trade route to Myanmar but also to South Asia. It can provide an alternative route to PRC trade with South Asia, which is conducted mainly in maritime mode around the Strait of Malacca. 
- The proposed extension is part of the India-Myanmar-Thailand trilateral highway, which links India to Myanmar, Thailand, and the rest of the GMS. India is upgrading the Tamu-Kalewa-Kalemyo road in Myanmar. Complemented by transport and trade facilitation (TTF) measures, this route can contribute to increased trade and investment between South Asia and the GMS.

Add the Boten-Oudomxay-Luang Prabang-Vang Vieng-Vientiane-Nong Khai-Udon Thani-Nakhon Ratchasima-Laem Chabang link to NSEC.

- This addresses another major omission in the GMS economic corridors, i.e., Vientiane being not part of any of the economic corridors.

- The Vientiane-Nong Khai-Bangkok route is the main trade route between the Lao PDR and Thailand, with Laem Chabang Port acting as a gateway port to landlocked Lao PDR. On the other hand, the route from Vientiane to Boten is the main land route between the PRC and the Lao PDR.

- The addition of this route in NSEC will expand the coverage of economic corridors in the Lao PDR and recognize its important location at the center of the subregion.

Include a Bangkok and Ha Noi link in NSEC using the Bangkok-Nakhon Ratchasima-Udon Thani-Sakon Nakhon-Nakhon PhanomThakhek-Na Phao-Chalo (via Route No. 12)-Vung Anh-Vinh-Ha Noi route.

- This will connect two important capitals and economic centers in the GMS-Bangkok and Ha Noi-and will serve as another link to the PRC (via Nanning).

- This will provide the Lao PDR with the shortest route to the maritime gateway at Vung Anh in Viet Nam, and support the Lao PDR's connectivity strategy for its transformation from a landlocked to a land-linked country.

- The inclusion of this route is in accord with the agreement reached during the Lao-Thai Transport Ministerial Meeting in July 2015 in Bangkok, in which Thailand agreed to consider the Lao PDR's request for assistance in upgrading National Road 12, with the Lao PDR in turn concurring with the inclusion of this route in Protocol 1 of the Cross-Border Transport Facilitation Agreement (CBTA).

- This route will shorten the distance between Bangkok and Ha Noi by at least 150 kilometers compared with the route through EWEC. It will open up new opportunities in response to market needs.

- Development of this route is one of the initiatives in the Ayeyarwady-Chao Phrya-Mekong Economic Cooperation Strategy Plan of Action, 2016-2018.

Include a link between Vientiane and Ha Noi using the Paksan-Nam Phao-Cau Treo-Vinh route with an extension to Vung Anh.

- The route from Vientiane to the new seaport in Vung Anh in Viet Nam provides landlocked Lao PDR with the shortest access to the sea. The Lao PDR and Viet Nam have signed a memorandum of understanding for the use by the Lao PDR of Vung Anh Port as one of the country's gateways to the sea.

- This route connects Vientiane and Ha Noi through Vinh, and reinforces the role of Vientiane in GMS economic corridor development.

- This route is parallel to the priority expressway alignment linking Vientiane to Ha Noi, for which a preliminary survey is being conducted by the Lao PDR and Viet Nam authorities.

The review further proposes that several complementary measures be considered.

\section{Adopting Corridor Classification System}

The adoption of the proposed changes in the configuration of the economic corridors will add more routes to the existing ones, so the question of investment prioritization arises. To address this issue, a corridor classification system should be adopted to guide the focus of interventions depending on the level of a particular corridor. For example, the main focus on corridors that have many missing links and/or poor road conditions would be on achieving physical connectivity. In corridors where physical 
connectivity has been substantially established, the focus would be on TTF, urban development, enterprise development, and investment promotion. An assessment of the state of development of the economic corridor routes will help in producing such a classification system.

\section{Clarifying Names of Routes or Subcorridors in North-South Economic Corridor and Southern Economic Corridor}

The names of the routes or subcorridors in NSEC and SEC and those in the GMS Transport Sector Strategy (TSS), 2006-2015 have caused some misunderstanding, if not confusion, because some corridors refer to the same routes but are called differently. For example, the North-South Corridor in the GMS TSS is equivalent to the Western Subcorridor of NSEC, while the Northern Corridor in the GMS TSS is equivalent to the Eastern Corridor of NSEC.

It is proposed that the names EWEC, NSEC, and SEC be retained, as these are already well-known to GMS stakeholders. However, it would be necessary to be clear about the specific route or subcorridor under NSEC and SEC that is being referred to, as there would be eight subcorridors in NSEC after reconfiguration, and four in SEC. In this regard, it is suggested that the subcorridors in NSEC and SEC be named using the main nodal points along their routes with corresponding acronyms NSEC-1, NSEC-2, SEC-1, SEC-2, etc. For example, the Western Subcorridor in NSEC would be called "Kunming-Chiang RaiBangkok via the Lao PDR or Myanmar Subcorridor (NSEC-1)," and so on.

\section{Adopting Network Approach to Greater Mekong Subregion Economic Corridor Development}

As the GMS moves to the next stage of economic corridor development, it is timely to consider shifting from an approach that focuses on each economic corridor separately to one that views the corridors as part of a network of economic corridors interacting with each other. First, from a practical standpoint, the various routes in EWEC, NSEC, and SEC should not be seen independently of each other, because ideally one should be able to travel, for instance, on a section of SEC and then move to a section of EWEC and NSEC, e.g., from Phnom Penh along SEC to Bangkok and Tak along NSEC and to Yangon along EWEC. Accordingly, it would be beneficial to view EWEC, NSEC, and SEC as part of an economic corridor network that allows sufficient flexibility on the routes to be taken subject to reasonable prerequisites and standards. Second, given the imperative for the development of railway and other modes of transport, including ports and inland waterways, the concept of a network of economic corridors may be more conducive to the development of a GMS multimodal transport system.

\section{Enhancing Process of Greater Mekong Subregion Economic Corridor Development}

During the country consultations held for this review, several concerns were raised regarding the process of GMS economic corridor development, which is at the center of the GMS Program and a unique feature of cooperation in the subregion. Greater efforts are needed to facilitate the transformation of transport corridors into economic corridors and maximize the benefits from this initiative. In particular, the following needs require special consideration:

- accelerating and creating a momentum for the implementation of the CBTA and broader TTF measures, given that all countries have now ratified the CBTA;

- extending the benefits of economic corridor development to as many areas as possible through the development of feeder roads and national networks that are effectively connected to GMS economic corridors; and

- addressing unmitigated migration from vulnerable GMS economies like Cambodia and the Lao PDR by expanding employment opportunities in these countries along and around economic corridors through the development of industrial clusters, special economic zones, and small and medium-sized enterprises that are linked to subregional or regional production networks and value chains. 



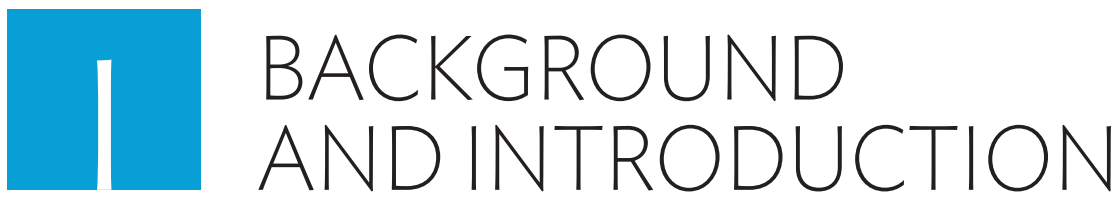

The economic corridor approach was adopted by the Greater Mekong Subregion (GMS) countries at the Eighth GMS Ministerial Conference held in Manila in 1998 to help accelerate subregional development. 'The GMS Ministers agreed that the development of economic corridors would be an effective means to link production, trade, and infrastructure within a specific geographic area. They identified potential economic corridors in the GMS running along its north-south and eastwest axes, based on the priority projects proposed in the Subregional Transport Sector Study conducted in 1995. ${ }^{2}$ These projects became the backbone of the East-West Economic Corridor (EWEC), North-South Economic Corridor (NSEC), and Southern Economic Corridor (SEC), which were subsequently designated as flagship programs under the Ten-Year GMS Strategic Framework, 2002-2012.,.4

In 2006, the GMS countries endorsed the GMS Transport Sector Strategy (TSS), 2006-2015, which proposed a GMS corridor network of nine corridors. ${ }^{5}$ EWEC, NSEC, and SEC, which are part of this network, are considered to be the priority corridors for transformation from transport to economic corridors. Thus, complementary efforts such as trade and transport facilitation, border and corridor towns development, investment promotion and enterprise development have been largely focused on EWEC, NSEC, and SEC. The development of GMS corridors as economic corridors continued to be at the center of the GMS Program under the succeeding GMS Strategic Framework, 2012-2022.,7

The need to review the configuration of EWEC, NSEC, and SEC to enhance their contribution to GMS development was first raised at the Fourth GMS Economic Corridors Forum (ECF) held in Mandalay, Myanmar in June 2012. More specifically, the review was deemed necessary to take into account the opening up of Myanmar and ensure that (i) there is a close match between the corridor routes and trade flows; (ii) GMS capitals and major urban centers are integrated into the corridor network; and (iii) the corridors are linked with maritime gateways. Discussions at the Seventh GMS ECF held in Kunming, Yunnan Province, the People's Republic of China (PRC) in June 2015, and the 20th GMS Ministerial Conference held in Nay Pyi Taw, Myanmar in September 2015, also drew attention to the need for such a review.

Changes in the configuration of GMS economic corridors respond to the dynamic nature of subregional development. These changes will help ensure that further investments in GMS economic corridor development are focused on areas with the best potential to become fully functioning economic corridors, thus maximizing their contribution to increased incomes and employment in the subregion. The purpose of this review is to come up with recommendations for possible extension and/or realignment of EWEC, NSEC, and SEC to enhance their effectiveness and efficiency in advancing economic integration in the GMS. A pragmatic approach will be taken, with proposed changes in the form of refinements more than overhaul, considering sunk costs in the existing corridor alignments and the need to give priority to completing ongoing work on these alignments. It is also important to avoid unnecessarily expanding the coverage of EWEC, NSEC, and SEC, as this may diffuse the focus of GMS economic corridor development.

Section II clarifies the concept and role of economic corridors in the context of GMS development, briefly citing related experience in the European Union (EU). Section III presents the current configuration of EWEC, NSEC, and SEC and tracks the milestones in their evolution. Section IV highlights the major gaps in the current configuration of the three economic corridors based on past studies and country consultations, and discusses changes that would address these gaps. Section $\vee$ presents the review's recommendations.

Summary of Proceedings. Eighth GMS Ministerial Conference. Manila. 2 October 1998.

Asian Development Bank (ADB). 1995. Subregional Transport Sector Study for the Greater Mekong Subregion: Final Report. Manila.

Adopted at the First GMS Summit held in Phnom Penh, Cambodia in November 2002.

ADB. 2002. Building on Success: A Strategic Framework for the Next Ten Years of the Greater Mekong Subregion Economic Cooperation Program. Manila. ADB. 2007. GMS Transport Sector Strategy 2006-2015: Coast to Coast and Mountain to Sea: Toward Integrated Mekong Transport Systems. Manila.

ADB. The GMS Economic Cooperation Program Strategic Framework, 2012-2022. Manila.

Adopted at the Fourth GMS Summit held in Nay Pyi Taw, Myanmar in December 2011. 


\section{GREATER MEKONG SUBREGION ECONOMIC CORRIDORS}

The concept of economic corridor development in the Greater Mekong Subregion (GMS) Program was articulated at the Eighth GMS Ministerial Conference. In their joint statement, the GMS Ministers declared that "GMS member countries will create economic corridors linking the subregion to major markets; nodal points within these economic corridors will serve as centers for enterprise development; economic corridors will be an expansion of key transport corridors so as to enhance economic activities and benefits, and over the longer term to build on the potential of the subregion as a land bridge serving the People's Republic of China (PRC), Southeast Asia, South Asia, and East Asia." " They named the following essential elements of GMS economic corridors: (i) sound economic rationale, including the basis for related economic zones; (ii) physical infrastructure connecting centers of economic activity to each other; (iii) streamlined policies and procedures to allow cross-border utilization of the corridor; (iv) site-specific physical infrastructure, and policy and regulatory framework; and (v) effective marketing strategy of the concept as a set of tangible investment opportunities.

As envisioned, a GMS economic corridor is not simply a connection between points $\mathrm{A}$ and $\mathrm{B}$, with a transport corridor being just the first step toward becoming an economic corridor. More specifically, an economic corridor consists of an integrated system of road, rail, and ports that interconnects (i) borders of GMS countries; (ii) centers of production (manufacturing hubs, industrial clusters, and economic zones); (iii) centers of demand (capitals and major urban centers); and (iv) gateways that include important seaports used for intra-regional and international trade. The areas of influence of GMS economic corridors extend beyond a single route, encompassing an economic zone running in parallel with the main transport artery. Economic corridors are able to attract investment in economic activities along and around their main routes, thus generating additional demand and increasing their viability. They are critical for economic integration in the GMS, because they not only facilitate cross-border movement of people, goods and services, labor, and capital along the corridors, but also promote the development of areas that can be accessed through improved connectivity.

Operationally, the economic corridor approach is aimed at (i) extending the benefits of improved transport links to remote and landlocked locations in the GMS, which have been disadvantaged by their lack of integration with more prosperous and better located neighboring areas; (ii) providing a spatial focus on GMS activities, with the main routes, growth centers, and nodal points serving as catalyst to the development of surrounding areas; (iii) serving as a mechanism for prioritizing and coordinating investments among neighboring countries; (iv) opening up opportunities for various types of investments from within and outside the GMS; (v) enhancing the impact of subregional activities through the clustering of projects; and (vi) generating tangible demonstration effects.

EWEC, NSEC, and SEC were designated as priorities for economic corridor development, because they (i) have the greatest potential to become foreign trade, investment, and tourist corridors; and (ii) have relatively significant sections that can be developed into hubs for regional trade, investment, and tourism. The term "economic corridor" affixed to EWEC, NSEC, and SEC does not mean that they have indeed become economic corridors. Instead, these names have been used to delineate which among the corridors would be priorities in terms of infrastructure development and related interventions needed to transform them into economic corridors. More generally, the name embodies the aspiration of GMS countries to move up to the next stage of economic integration in which transport corridors become economic arteries for the seamless flow of people, trade, investment, and services among GMS countries.

8 Footnote 1, page 1. 
In some respects, the approach being taken in the GMS is similar to that being pursued in the EU to promote integration through increased interconnectivity and mobility. In January 2014, the European Union (EU) adopted a new approach for developing the Trans-European Transport Network (TEN-T) that connects the continent along its east and west, and north and south axes. ${ }^{9}$ Nine "core network corridors" were designated to focus investment on the primary routes that would help (i) "close the gap between Member States' transport networks"; (ii) "remove bottlenecks that still hamper the smooth functioning of the internal market"; (iii) "build missing cross-border connections"; (iv) "integrate urban areas into the TEN-T"; and (v) "promote multimodal integration and interoperability".10,11

Work plans for each of the corridors have been approved, and priority projects are being funded by the Connecting Europe Facility, the Cohesion Fund, and the European Regional Development Fund that involve both public and private resources. ${ }^{12}$ The formulation and implementation of the work plans entail regular consultation with a corridor forum, which is a consultative body consisting of member states and various stakeholders.

European Commission. Infrastructure-TEN-T_Connecting Europe. Corridors. http://ec.europa.eu/transport/themes/infrastructure_en. 10 Footnote 8.

1 European Commission. Infrastructure-TEN-T-Connecting Europe. What do we want to achieve? http://ec.europa.eu/transport/themes/infrastructure.

12 The Cohesion Fund and European Regional Development Fund aim at reducing social and economic disparities between regions and promoting sustainable development. 


\section{EVOLUTION OF THE GREATER MEKONG SUBREGION CORRIDORS}

Greater Mekong Subregion (GMS) corridors have evolved in three stages. The first stage, from 1992 to 1997, laid the foundations for the development of GMS corridors. In 1992, seven priority road projects were identified during country consultations that were conducted prior to the inaugural meeting of the GMS countries in October of that year. ${ }^{13}$ This set of projects was refined in the Subregional Transport Sector Study for the GMS (the Study) conducted in 1993. ${ }^{14}$ The draft report of the Study was presented at the Third GMS Ministerial Conference held in Ha Noi, Viet Nam in April 1994, and its final report was endorsed at the Fourth GMS Ministerial Conference held in Chiang Mai, Thailand in September 1994. Nine priority road projects were identified in the Study. During 1992-1994, new routes were added while some were shelved, manifesting an evolving process of route selection and delineation. Table 1 shows the key milestones in the evolution of GMS corridors.

\section{TABLE 1: Key Milestones in the Evolution of the Greater Mekong Subregion Corridors}

\begin{tabular}{|c|c|c|}
\hline Year & Milestones & Remarks \\
\hline 1993-1994 & Conduct and adoption of the Transport Sector Study for the GMS & Priority transport links and investments were identified. \\
\hline 1998 & Adoption of the economic corridor approach & The approach was adopted at the Eighth GMS Ministerial Conference. \\
\hline 2000 & $\begin{array}{l}\text { Configuration of EWEC, NSEC, and SEC defined; EWEC, NSEC, } \\
\text { and SEC designated as priority initiatives }\end{array}$ & $\begin{array}{l}\text { The configuration was defined at the Ninth GMS Ministerial } \\
\text { Conference. EWEC consisted of a single route, while NSEC and SEC } \\
\text { had two branches each. }\end{array}$ \\
\hline 2002 & $\begin{array}{l}\text { Designation of EWEC, NSEC, and SEC as flagship programs } \\
\text { under the Ten-Year GMS Strategic Framework, 2002-2012 }\end{array}$ & $\begin{array}{l}\text { Designation as flagship programs was endorsed at the First GMS } \\
\text { Summit held in Phnom Penh, Cambodia. }\end{array}$ \\
\hline 2004 & $\begin{array}{l}\text { Inclusion of Guangxi Zhuang Autonomous Region (Guangxi) } \\
\text { of the PRC in the GMS }\end{array}$ & $\begin{array}{l}\text { An additional branch was added to NSEC linking Nanning of Guangxi } \\
\text { to Ha Noi. }\end{array}$ \\
\hline 2006 & Adoption of the GMS Transport Sector Strategy, 2006-2015c & $\begin{array}{l}\text { Nine corridors making up a GMS corridor network were identified, } \\
\text { with EWEC, NSEC, and SEC being subsets of these corridors. }\end{array}$ \\
\hline 2009-2010 & Adoption of SAPs for EWEC, NSEC, and SEC & $\begin{array}{l}\text { Some changes in the configuration of NSEC and SEC proposed by } \\
\text { GMS countries were incorporated. }\end{array}$ \\
\hline 2011 & Extension of SEC from Bangkok to Dawei & $\begin{array}{l}\text { This was the only change in the configuration of the economic } \\
\text { corridors since the adoption of SAPs. }\end{array}$ \\
\hline
\end{tabular}

PRC $=$ People's Republic of China, EWEC $=$ East-West Economic Corridor, GMS = Greater Mekong Subregion, NSEC = North-South Economic Corridor, SAPs $=$ strategies and action plans, $\mathrm{SEC}=$ Southern Economic Corridor.

a Kunming-Bangkok and Kunming-Ha Noi-Hai Phong in NSEC; and Bangkok-Phnom Penh-Ho Chi Minh City-Vung Tau and Bangkok-Siem Reap-Stung Treng-Pleiku-Quy Nhon in SEC.

b ADB. 2002. Building on Success: A Strategic Framework for the Next Ten Years of the Greater Mekong Subregion Economic Cooperation Program. Manila.

c ADB. 2007. GMS Transport Sector Strategy 2006-2015: Coast to Coast and Mountain to Sea: Toward Integrated Mekong Transport Systems. Manila.

Source: ADB Study Team.

The second stage of GMS corridor development, from 1998 to 2007, started with the adoption of the economic corridor approach and the designation of East-West Economic Corridor (EWEC), North-South Economic Corridor (NSEC), and Southern Economic Corridor (SEC) as priority corridors in 1998. The configurations of EWEC, NSEC, and SEC were subsequently defined at the Ninth GMS Ministerial Conference held in Manila in January 2000, largely based on the nine priority road projects in the Subregional Transport Sector Study (Figure 1).

13 M. Ishida and I. Isono. 2012. Old, New and Potential Economic Corridors in the Mekong Region in M. Ishida ed. Emerging Economic Corridors in the Mekong Region. BRC Research Report No. 8. Bangkok Research Center.

14 ADB. 1995. Subregional Transport Study for the Greater Mekong Subregion: Final Report. Manila. 


\section{Figure 1: Greater Mekong Subregion Economic Corridors, 2000-2008}

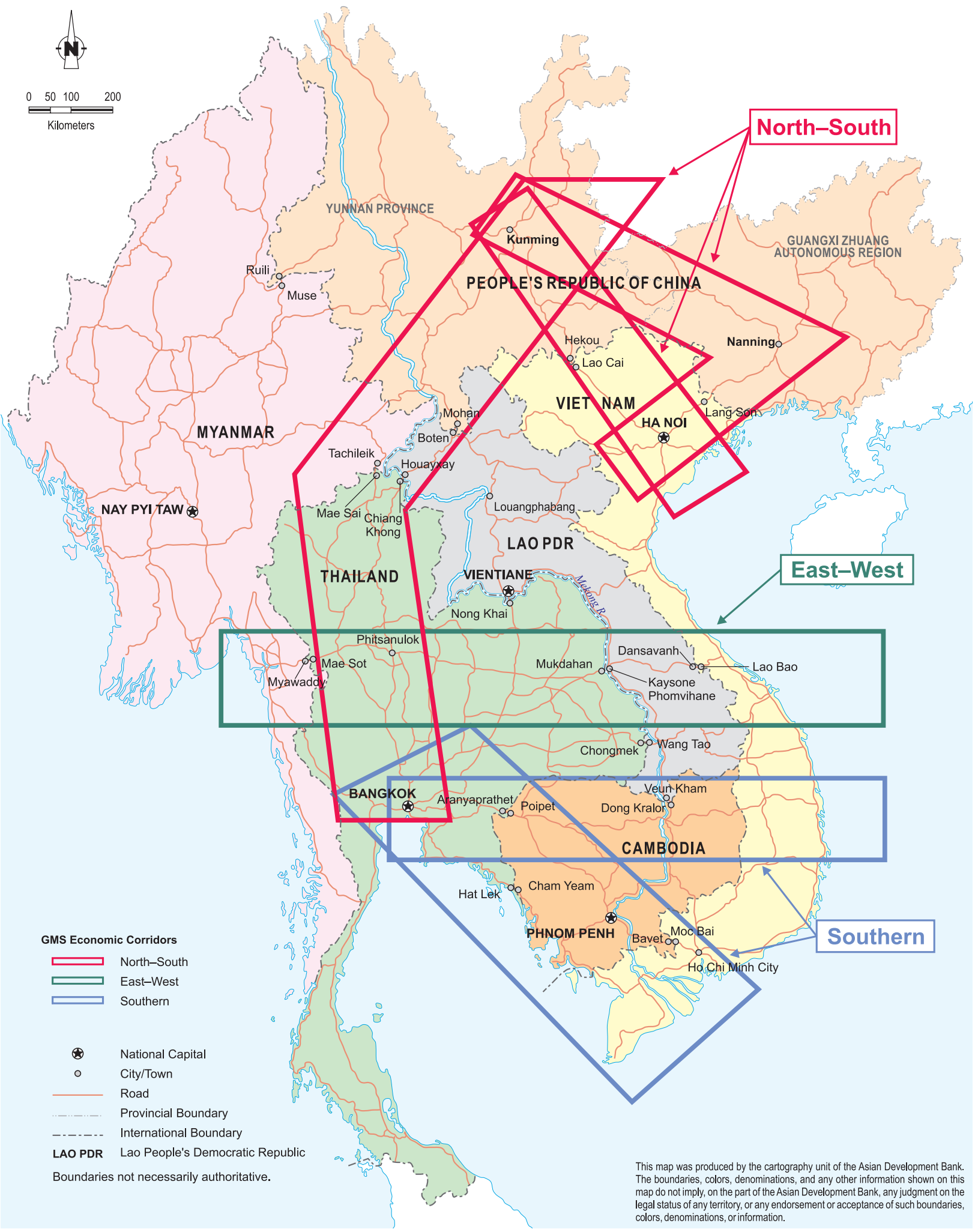

GMS = Greater Mekong Subregion

Source: ADB. 2002. Building on Success: A Strategic Framework for the Next Ten Years of the Greater Mekong Subregion Economic Cooperation Program. Manila. 


\section{Figure 2: Greater Mekong Subregion Corridor Network in Transport Sector Strategy, 2006-2015}

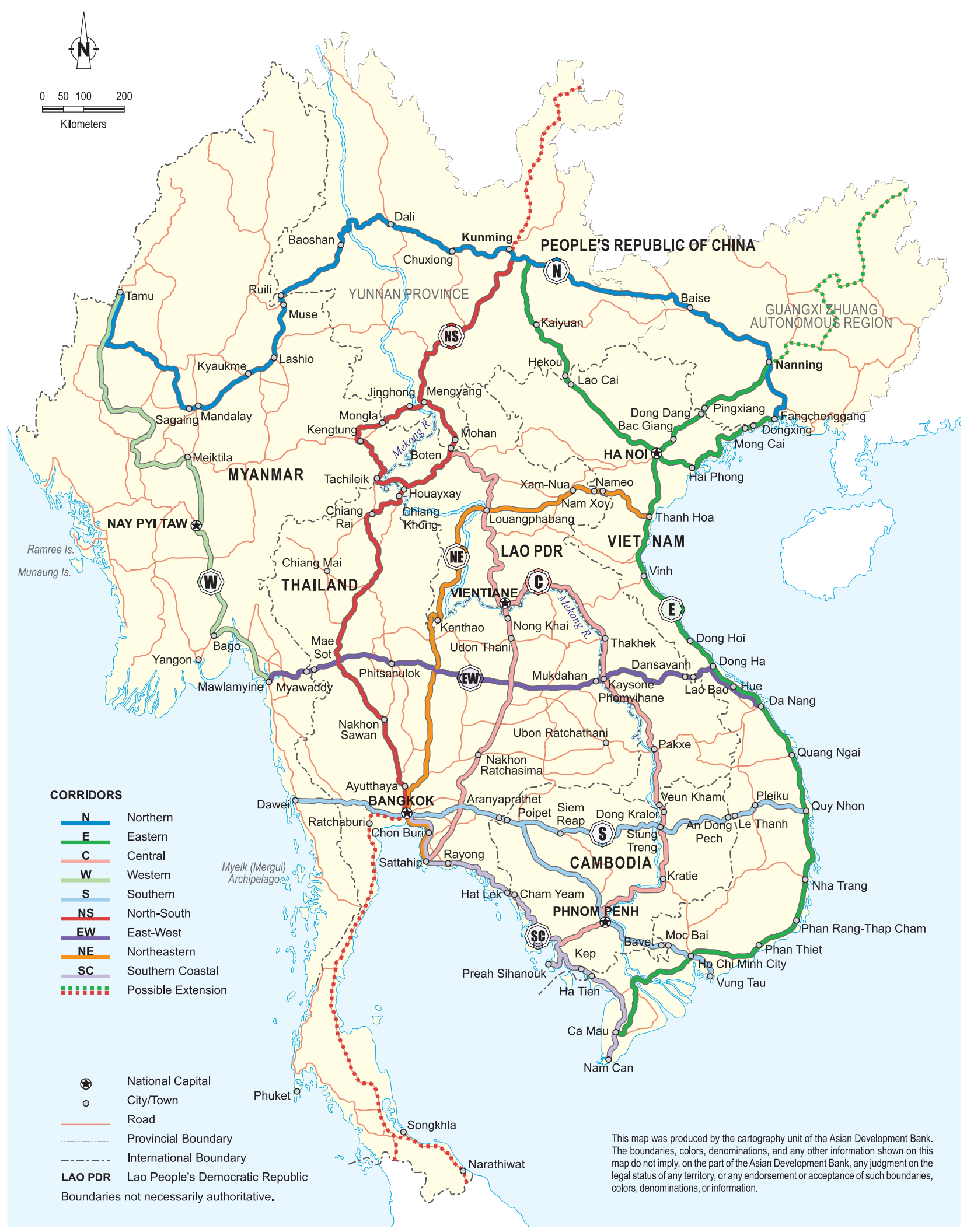

Source: ADB. 2007. GMS Transport Sector Strategy 2006-2015: Coast to Coast and Mountain to Sea: Toward Integrated Mekong Transport Systems. Manila. 
Recognizing the need to take account of developments in the subregion since 1994, including Guangxi Zhuang Autonomous Region (Guangxi) of the PRC, the study was updated and a new GMS Transport Sector Strategy (TSS) covering 2006-2015 was endorsed. The GMS TSS identified and prioritized investment and technical assistance projects, formulated action plans for implementation, and designed a GMS corridor network consisting of nine corridors (Figure 2). The change in the configuration of the GMS economic corridors during this stage was the addition of a branch in NSEC linking Nanning of Guangxi to Ha Noi in 2004.

The third stage, from 2008 onward, began with the formulation of the strategies and action plans (SAPs) for EWEC, NSEC, and SEC, which required that their alignment be more precisely defined and confirmed by the GMS countries. Based on country consultations conducted in 2008 as part of the SAP formulation process, certain changes in the alignment and configuration of NSEC and SEC were adopted, with most of the amendments being in the SEC where two subcorridors and an intercorridor link were added. ${ }^{15}$ The SEC was later extended from Bangkok to Dawei in 2011. ${ }^{16}$ Table 2 compares the original alignment and configuration of NSEC and SEC with the alignment and configuration in their respective SAPs.

\section{TABLE 2: Original and Amended Configuration of North-South Economic Corridor and Southern Economic Corridor}

\begin{tabular}{|c|c|}
\hline Original & Amended \\
\hline \multicolumn{2}{|c|}{ NSEC } \\
\hline $\begin{array}{l}\text { Before Guangxi Zhuang Autonomous Region (Guangxi) joined GMS } \\
\text { - Kunming-Chiang Rai-Bangkok via the Lao PDR or Myanmar } \\
\text { - Kunming-Ha Noi-Hai Phong } \\
\text { After Guangxi joined GMS: } \\
\text { - Kunming-Chiang Rai-Bangkok via the Lao PDR or Myanmar } \\
\text { - Kunming-Ha Noi-Hai Phong } \\
\text { - Nanning-Ha Noi-Hai Phong }\end{array}$ & $\begin{array}{l}\text { Kunming-Chiang Rai-Bangkok via the Lao PDR or Myanmar } \\
\text { (Western Subcorridor) } \\
\text { - Kunming-Ha Noi-Hai Phong (Central Subcorridor) } \\
\text { - Nanning-Ha Noi via Pingxiang in the PRC and Dong Dang in Viet Nam, } \\
\text { or via Fangcheng and Dongxing in the PRC and Mon Cai in Viet Nam } \\
\text { (Eastern Subcorridor) }\end{array}$ \\
\hline \multicolumn{2}{|r|}{ SEC } \\
\hline $\begin{array}{l}\text { - Bangkok-Phnom Penh-Ho Chi Minh City-Vung Tau } \\
\text { - Bangkok-Siem Reap-Stung Treng-Ratanakiri-O Yadav-Pleiku- } \\
\text { Quy Nhon }\end{array}$ & $\begin{array}{l}\text { - Bangkok-Phnom Penh-Ho Chi Minh City-Vung Tau (Central Subcorridor) } \\
\text { Bangkok-Siem Reap-Stung Treng-Ratanakiri-O Yadav-Pleiku-Quy Nhon } \\
\text { (Northern Subcorridor) } \\
\text { Bangkok-Trat-Koh Kong-Kampot-Ha Tien-Ca Mau City-Nam Can } \\
\text { (Southern Coastal Subcorridor) } \\
\text { Sihanoukville-Phnom Penh-Kratie-Stung Treng-Dong Kralor (Tra Pang } \\
\text { Kriel)-Pakse-Savannakhet (Intercorridor Link, which connects the three } \\
\text { SEC subcorridors with EWEC) }\end{array}$ \\
\hline
\end{tabular}

PRC = People's Republic of China, EWEC = East-West Economic Corridor, GMS = Greater Mekong Subregion, Lao PDR = Lao People's Democratic Republic, NSEC = North-South Economic Corridor, SEC = Southern Economic Corridor.

Source: ADB Study Team.

The present configuration of EWEC, NSEC, and SEC is shown in Figure 3, while an overlay of the routes they cover on the nine-corridor network of the GMS TSS is shown in Figure 4. Except for a few small sections, the alignment of the routes in EWEC, NSEC, and SEC coincides with those in the GMS TSS corridor network. However, not all nine corridors in the GMS TSS are part of EWEC, NSEC, and SEC.

15 ADB. 2010. Strategy and Action Plan for the Greater Mekong Subregion East-West Economic Corridor. Manila; ADB. 2010. Toward Sustainable and Balanced Development: Strategy and Action Plan for the Greater Mekong Subregion North-South Economic Corridor. Manila; and ADB. 2010. Sharing Growth and Prosperity: Strategy and Action Plan for the Greater Mekong Subregion Southern Economic Corridor. Manila. The delineation of EWEC and NSEC was endorsed at the 15th GMS Ministerial Conference (Thailand, June 2009), and of NSEC at the 16th GMS Ministerial Conference (Ha Noi, August 2010).

16 The addition of Dawei to SEC was endorsed at the 17th Ministerial Conference held in August 2011. 


\section{Figure 3: Present Configuration of East-West Economic Corridor, North-South Economic Corridor, and Southern Economic Corridor}

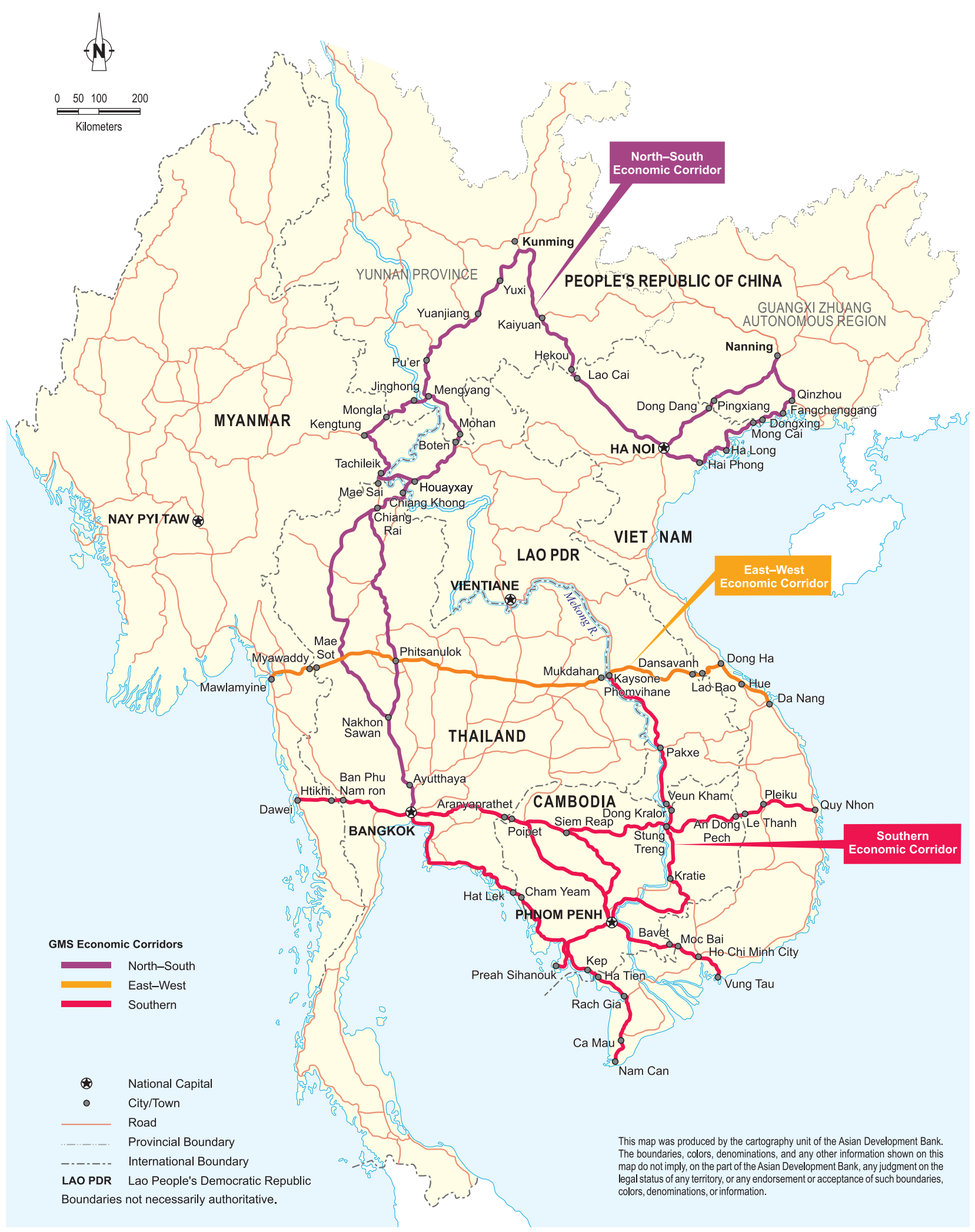

GMS = Greater Mekong Subregion

Source: ADB Study Team. 


\section{Figure 4: Overlay of the Greater Mekong Subregion Economic Corridors on the Greater Mekong Subregion Corridor Network}

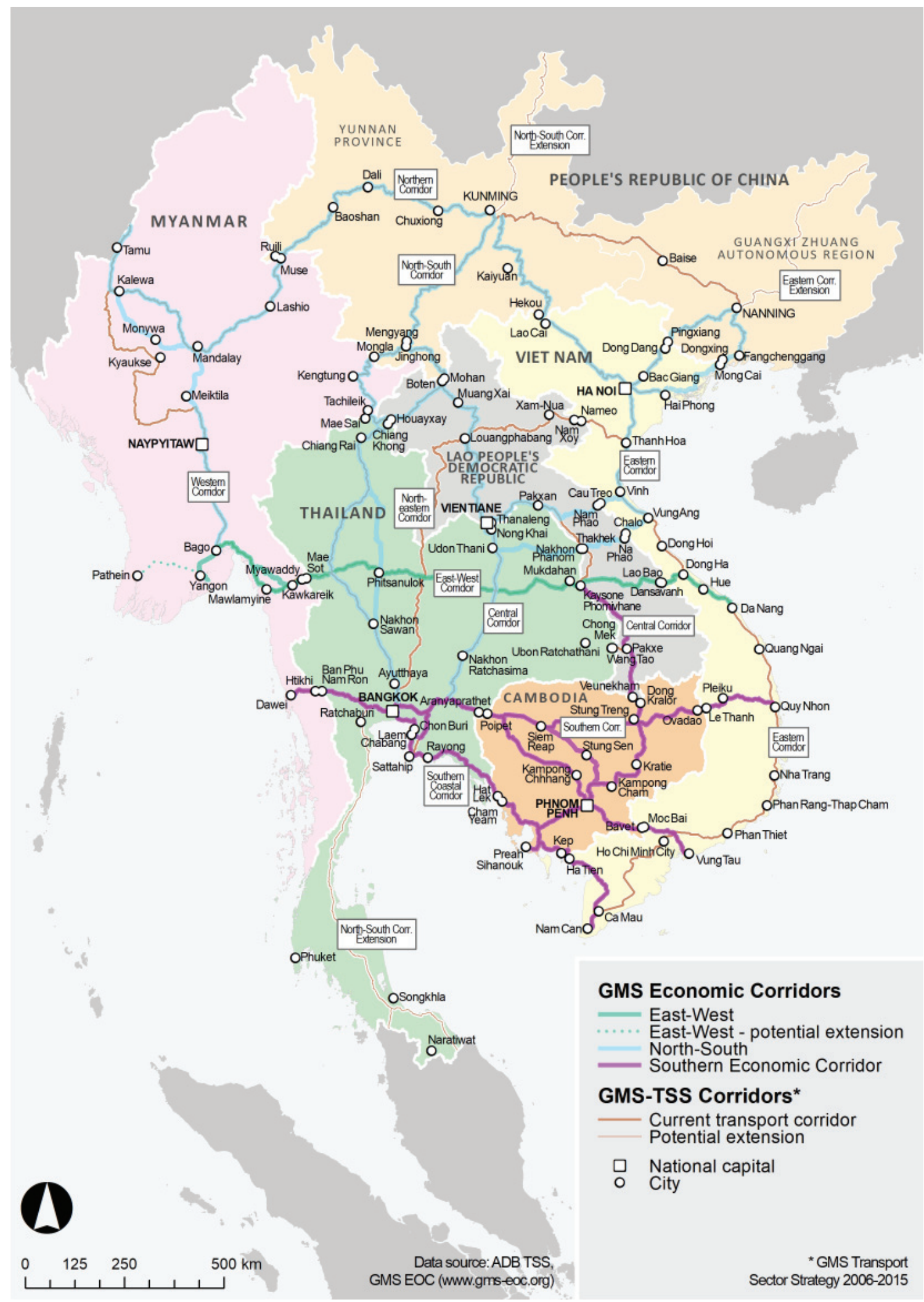

GMS = Greater Mekong Subregion, TSS = Transport Sector Strategy. Source: ADB Study Team 


\section{A. Assessment of Corridor Alignment}

An initial assessment of road infrastructure and associated transport and logistics services for the enhancement of trade facilitation in the Greater Mekong Subregion (GMS) was prepared and presented at the Fourth Economic Corridors Forum (ECF) in Mandalay, Myanmar in June 2012. ${ }^{17}$ A follow-on study was conducted to elaborate on the findings of the initial assessment and to provide inputs in the formulation of the GMS Regional Investment Framework, 2013-2022.18 The draft final report of the follow-on study was presented at the 16th GMS Subregional Transport Forum held in Nay Pyi Taw, Myanmar in October 2012.

The objectives of the follow-on study were to undertake further transport and logistics assessments of the GMS corridors, and to identify refinements that would promote economic viability through strengthening links with maritime gateways and trade, and enhancing urban growth nodes. The study (i) examined the trade demand of each of the GMS countries and identified the primary trade routes on a national basis, including quantification of likely flows along the corridors; (ii) identified possible changes in trading patterns that could potentially impact on future traffic flows; (iii) examined the movement of the projected international trade to identify the key trade-related sections of the corridor network, as well as detect any potential missing linkages; and (iv) based on the above, identified trade routes and recommended some changes in the configuration of the corridors.

From the viewpoint of GMS development as a whole, the use of trade flows as the sole basis for designating certain routes as GMS economic corridors is considered too narrow and inadequate. In some sections of GMS corridors, trade flows may be limited at present. However, cross-border flows of tourism and other types of trade in services such as health and education services are substantial, and hence need to be taken into account in delineating GMS economic corridors. Appendix 1 plots the location of special economic zones (SEZs) in the GMS. Appendix 2 shows population distribution along and around the corridors. Although the follow-on study focused only on the trade aspects of corridor development, it provides a useful reference for the identification of possible changes in the configuration of East-West Economic Corridor (EWEC), North-South Economic Corridor (NSEC), and Southern Economic Corridor (SEC). The major findings of the study are as follows:

- The viability of GMS corridors largely depends on the overall route having at least two important centers of economic activity that stimulate and generate the movement of goods. These movements need not necessarily be end to end, but could also be to and from the centers to other smaller concentrations of economic activity along or around that route.

- Some corridors have a greater potential than others, or the necessary critical mass, to become economic corridors. For example, a corridor that has larger concentrations of economic activity will tend to have a greater chance of becoming a sustainable economic corridor. Similarly, certain sections of corridors differ in their potential to function as economic corridors.

- Economic corridors cannot be expected to be completely developed along their total length and would more likely consist of economic sections that are elliptical in shape due to the influence of the corridor. Difficult terrain and low population density in certain sections make them less attractive to investment in economic activities.

- Maritime transport dominates trade and is expected to do so in the medium to long term, accounting for $90 \%$ of overall GMS trade and 70\% of intra-GMS trade. The dominance of maritime transport is due to the high proportion of bulk cargoes such as fuel, steel, cement, and minerals. The road subsector dominates land transport, mainly as collection and distribution service for ports-based trade. Rail transport is underutilized due to the limited network and lack of international links.

17 ADB. 2012. Initial Assessments of Road Transport Infrastructure and Transport and Logistic Services for Trade Facilitation in the GMS Countries. Consultant's report. Manila (TA 7851-REG).

18 ADB. 2012. Support for Implementing Action Plan for Transport and Trade Facilitation in the GMS (Subproject 1) Transport and Logistics Assessment Follow-up Study. Draft final report. Manila. 
- Despite the dominance of maritime transport, road transport will continue to play an important role in trade among GMS countries. Even a relatively small increase in tonnage can have a major impact on international road traffic due to the small load sizes. This suggests that priority road infrastructure investments will be needed in key sections of the GMS corridors that pass through busy borders and are close to major seaport conurbations.

- From a trade facilitation perspective, the dominance of maritime transport suggests that effective connectivity with the major ports is an important consideration when reviewing corridor alignments, followed by connectivity between the major centers of production in each country and the centers of demand in the other GMS countries.

- Major changes in trade in the GMS would mainly relate to developments in Myanmar, which are expected to generate a significant increase in trade with neighboring countries, especially with the People's Republic of China (PRC) and Thailand. This will place additional pressure on the improvement of cross-border linkages, as a major part of this trade passes through its land borders. As Myanmar's trade with the rest of the world is also expected to increase significantly, there would also be increased pressure on maritime infrastructure and connectivity to the ports within Myanmar.

- Cross-border trade was found to be largest in the following border crossings:

- Cambodia-Thailand $\rightarrow$ Poipet-Aranyaprathet (SEC)

- Cambodia-Viet Nam $\rightarrow$ Bavet-Moc Bai (SEC)

- Lao PDR-Thailand $\rightarrow$ Vientiane-Nong Khai (not part of any economic corridor)

- Myanmar-Thailand $\rightarrow$ Myawaddy-Mae Sot (EWEC) and Tachilek-Mae Sai (NSEC)

- Myanmar-PRC $\rightarrow$ Muse-Ruili (presently not part of any economic corridor)

- Lao PDR-PRC $\rightarrow$ Boten-Mohan (NSEC)

- Viet Nam-PRC $\rightarrow$ Hekou-Lao Cai and Pingxiang-Lang Son (NSEC)

- The primary cross-border trade routes in the GMS were identified as follows:

- Kunming-Bangkok via Lao PDR (NSEC)

- Bangkok-Phnom Penh-Ho Chi Minh City (SEC)

- Bangkok-Vientiane (presently not part of any economic corridor)

- Bangkok-Yangon via Mae Sot-Myawaddy (presently not part of any economic corridor)

- Kunming-Mandalay via Muse-Ruili (presently not part of any economic corridor)

- Kunming-Ha Noi-Hai Phong (NSEC)

\section{B. Criteria for Realignment and/or Extension}

In reviewing the configuration of EWEC, NSEC, and SEC, the primary concern is to ensure that: (i) developments arising from the opening up of Myanmar are taken into account; (ii) corridors include and link all GMS capitals and major economic centers; (iii) corridors are connected to key GMS maritime gateways and industrial hubs; and (iv) major trade flows are reflected in the alignment of the corridors.

Viewed from these requisites, the following glaring gaps need to be addressed by extending and/or realigning the economic corridors:

- There is relatively limited involvement of the Lao PDR and Myanmar in EWEC and NSEC.

- Yangon, Nay Pyi Taw, and Vientiane are not included in any economic corridor.

- Yangon Port is not linked to any economic corridor.

- The principal cross-border trade routes between the PRC and Myanmar; Myanmar and Thailand; and the PRC, the Lao PDR, and Thailand are not reflected in the alignment of the economic corridors.

Figure 3 illustrates the limited coverage of the economic corridors in the Lao PDR and Myanmar. This is also evident in Figure 5, which shows the intercountry distribution of EWEC, NSEC, and SEC in terms of the estimated country-wise length of the economic corridors as a percentage of the total length of the corridors. Only $12 \%-14 \%$ of the lengths of EWEC, NSEC, and SEC are in Myanmar, and a similar percentage of the lengths of EWEC and NSEC are in the Lao PDR. Myanmar was actually not 
part of the SEC before the inclusion of Dawei in 2011. As regards the primary trade routes cited above, only three are part of EWEC, NSEC, and SEC (Kunming-Bangkok via Lao PDR, Bangkok-Phnom Penh-Ho Chi Minh City, and Kunming-Ha NoiHai Phong). The other three (Bangkok-Vientiane, Bangkok-Yangon via Mae Sot-Myawaddy, and Kunming-Mandalay via Muse-Ruili) are not included in any of the economic corridors.

\section{Figure 5: Intercountry Distribution of the Greater Mekong Subregion Economic Corridors (\%)}

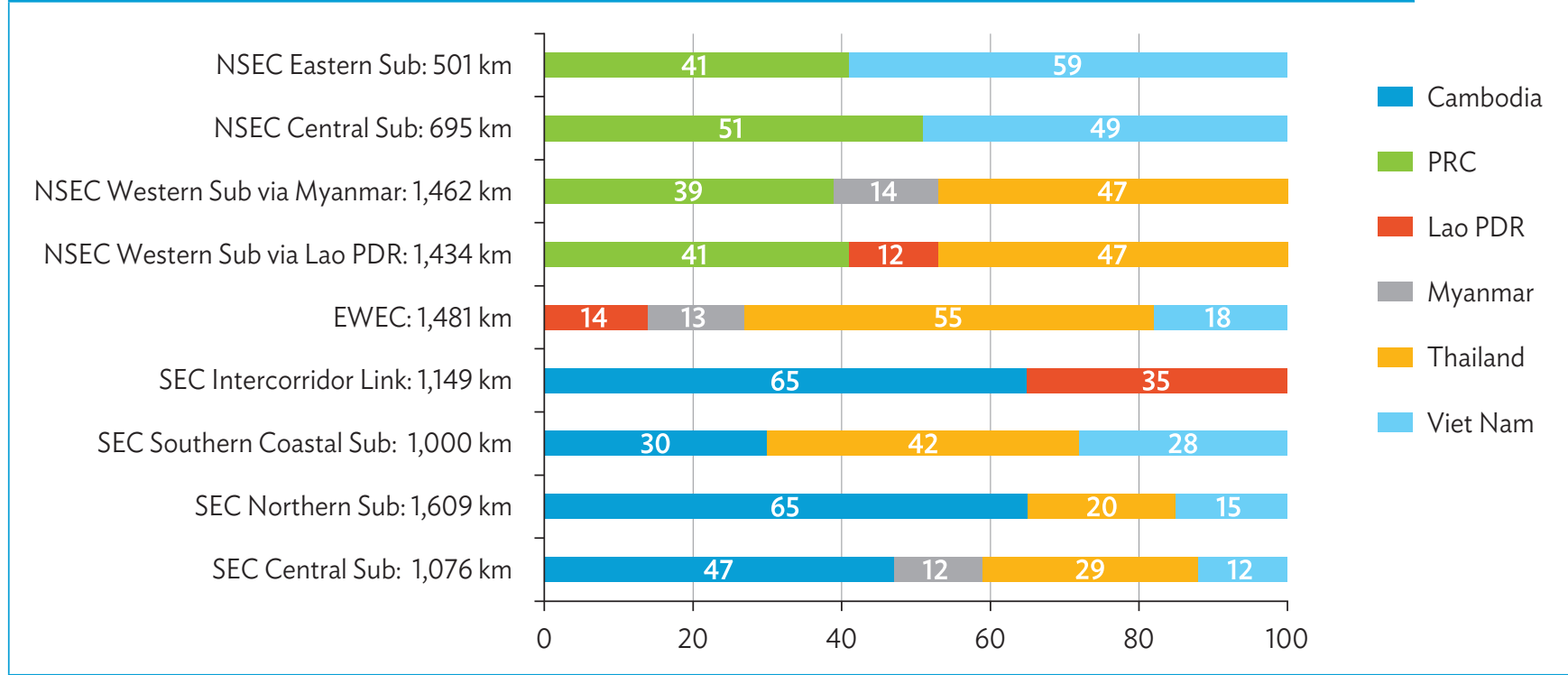

PRC = People's Republic of China, EWEC = East-West Economic Corridor, GMS = Greater Mekong Subregion, km = kilometer, Lao PDR = Lao People's Democratic Republic, NSEC $=$ North-South Economic Corridor, SEC = Southern Economic Corridor, Sub = Subcorridor.

Source: Updated Figure 1 in P. Srivastava. 2011. Regional Corridors Development in Regional Cooperation. ADB Economics Working Paper Series. No. 258. Manila: ADB.

\section{Proposed Corridor Realignment and/or Extension}

Based on the foregoing discussion and consultation with the GMS countries, ${ }^{19}$ some proposals for realignment and/or extension have been identified. These are shown in yellow lines in Figure 6, and presented below together with the rationale for their inclusion.

\section{East-West Economic Corridor}

Include an extension at the western end of EWEC to Yangon-Thilawa using the Myawaddy-Kawkareik-Eindu-Hpa-An-ThatonKyaikto-Payagi-Bago-Yangon-Thilawa route, with a possible extension to Pathein. ${ }^{20}$

- This addresses major omissions in the configuration of GMS economic corridors-the absence of Yangon and Yangon Port, Myanmar's principal gateway port for imports and exports, in any of the corridors.

- The Bangkok-Yangon route through Mae Sot-Myawaddy is the primary trade route between Thailand and Myanmar. The development of this route is of high priority, as trade between the two countries is expected to grow rapidly as a result of the new economic and political situation in Myanmar. In particular, a significant increase in traffic at the western end of EWEC between Thailand and Myanmar is expected. There is evidence of latent demand resulting from prior trade

19 Country consultations were conducted during March and early April 2016 to discuss various aspects of the review of the configuration of GMS economic corridors.

20 A new alignment between Kyaikto and Yangon is being planned to shorten the route to Yangon and bypass the congested sections in Kyaikto, Payagi, and Bago. 


\section{Figure 6: Proposed Realignment and/or Extension of the Greater Mekong Subregion Economic Corridors}

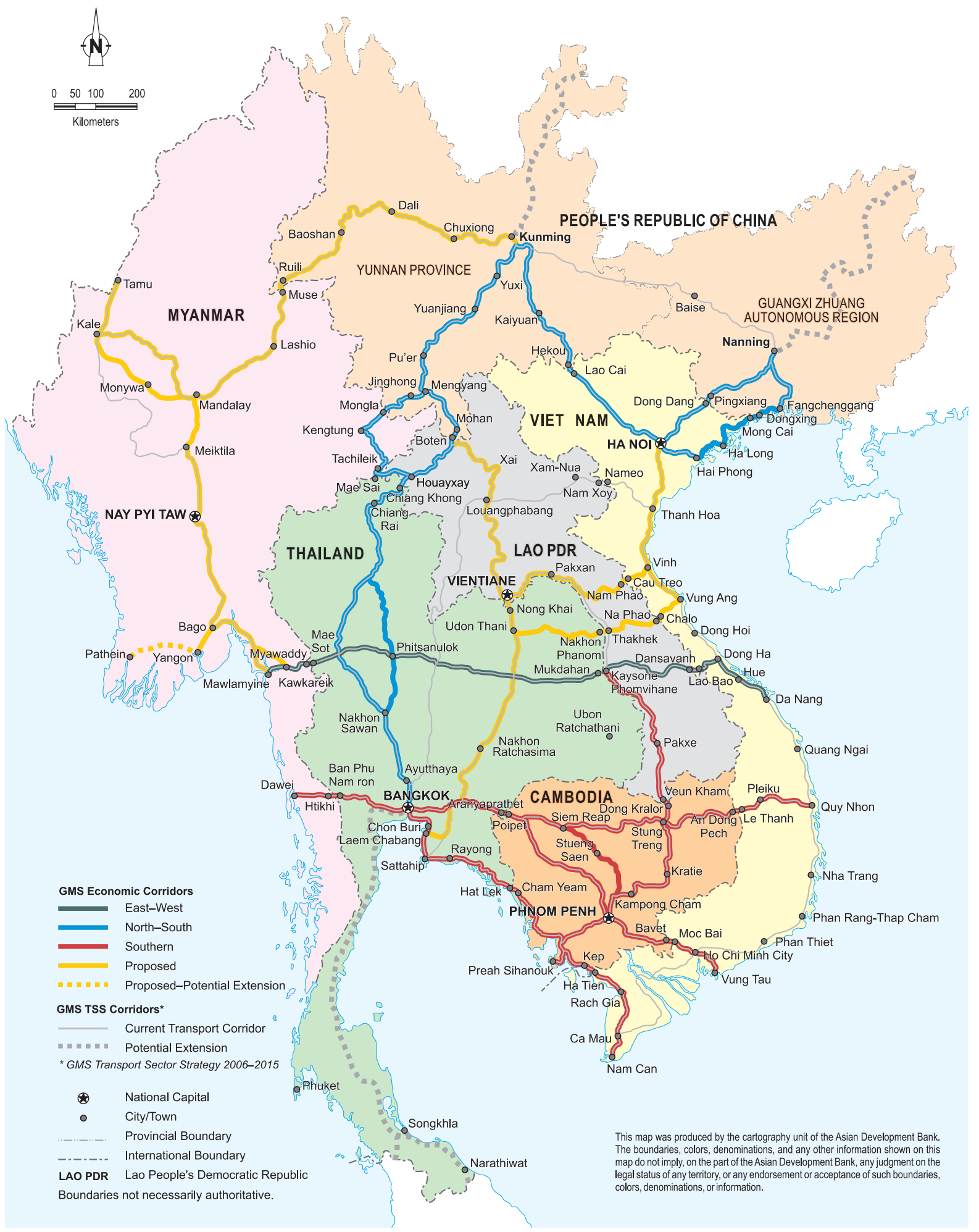

GMS = Greater Mekong Subregion, TSS = Transport Sector Strategy.

Note: The maps are based on available geographic information system base layers, in particular (i) Open Street Map, (ii) Digital Chart of the World, and (iii) national road data sets collected through ADB projects. Other information (e.g., borders, towns, hill shading) are from the GMS Atlas of the Environment.

Source: ADB Study Team. 
restrictions, suggesting that current volumes along this route can be expected to grow rapidly. Exports and imports through the Mae Sot-Myawaddy border increased threefold during 2013-2015, and in just the first 3 months of 2016 there were already 70\% more exports and imports than during the whole 2015 (Appendix 3).

- The ongoing projects for the improvement of this route are (i) the Eindu-Kawkareik Road Improvement Project funded by the Asian Development Bank, and (ii) the Mae Sot-Myawaddy Border Crossing and Infrastructure Improvements Project financed by the Government of Thailand. Thilawa is being developed by the Government of Myanmar in conjunction with the private sector as an SEZ, ${ }^{21}$ and Myawaddy by the Government of Myanmar as a special border economic and industrial zone.

- The proposed realignment of EWEC links cities with relatively large populations and emerging industrial hubs, and crosses rural areas with good potential to be linked to agricultural value chains. Many tourist attractions are also located along the proposed route. The Pathein-Yangon or Thilawa-Myawaddy section links the two most important agricultural areas of Myanmar - the Ayeyarwady Delta and the East Bago, Mon, and Kayin region. ${ }^{22}$

- The future connection of Pathein to EWEC can also be considered because of Pathein's potentials for development of agriculture, forestry, and tourism. All critical bridges from Pathein to Yangon already exist.

\section{North-South Economic Corridor}

Include the Kunming-Dali-Ruili-Muse-Mandalay-Nay Pyi Taw-Yangon route in NSEC.

- This is the main trade route between the PRC and Myanmar. Cross-border trade between the PRC and Myanmar at the Muse-Ruili border gate is the largest among all border gates in Myanmar (Appendix 3). The volume of trade that crosses Muse from Ruili is around 11 times greater than the second largest which is at the Mae Sot-Myawaddy border between Myanmar and Thailand. The Mandalay-Nay Pyi Taw-Yangon route is the main trade corridor within Myanmar.

- The roads along this route, particularly in the northern section that passes through difficult mountainous terrain, require substantial improvement to handle increased traffic. Complementary investments such as development of inland container depots will also be necessary to increase the viability of the corridor. Inclusion of this route in NSEC can sharpen the focus and strengthen efforts to improve infrastructure and promote investment along this corridor.

Add an extension to the Kunming-Dali-Ruili-Muse-Mandalay-Nay Pyi Taw-Yangon route to link Mandalay to Tamu at the border with India, using the Mandalay-Kalewa-Tamu route via Monywa or Shwebo. ${ }^{23}$

- The proposed extension expands the coverage of GMS economic corridors in Myanmar, and recognizes Myanmar's role as a land bridge to South Asia.

- Although cross-border trade between India and Myanmar is small compared with Myanmar's cross-border trade with the PRC and Thailand (Appendix 3), the prospects are favorable for increased trade and investment if bottlenecks in infrastructure, border facilities and formalities, and trade financing are addressed.

- The Kunming-Dali-Ruili-Muse-Mandalay-Nay Pyi Taw-Yangon route, especially the Mandalay-Muse-Ruili section, is expected to increase in importance not only as a trade route to Myanmar but also to South Asia. It can provide an alternative route to PRC trade with South Asia, which is conducted mainly in maritime mode around the Strait of Malacca.

- The proposed extension is part of the India-Myanmar-Thailand trilateral highway, which links India to Myanmar, Thailand, and the rest of the GMS. India is upgrading the Tamu-Kalewa-Kalemyo road in Myanmar. Complemented by transport and trade facilitation (TTF) measures, this route can contribute to increased trade and investment between South Asia and the GMS.

21 A. Min and T. Kudo. 2012. Newly Emerging Industrial Development Nodes in Myanmar: Ports, Roads, Industrial Zones along Economic Corridors in M. Ishida ed. Emerging Economic Corridors in the Mekong Region. BRC Research Paper No. 8. Bangkok Research Center.

22 ADB. 2016. Myanmar Regional Cooperation and Integration Assessment. Unpublished. Draft paper was prepared to support the proposed country partnership strategy between the Government of Myanmar and ADB.

23 ADB Institute. 2015. Connecting South Asia and Southeast Asia. Tokyo. This publication analyzes how closer regional cooperation between South Asia and Southeast Asia can benefit both regions. It examines how improved physical connectivity and associated soft infrastructure can foster closer economic ties between South Asia and Southeast Asia, and concludes that improving transport and energy connectivity is the crucial building block for greater economic integration between the two regions. 
Add the Boten-Oudomxay-Luang Prabang-Vang Vieng-Vientiane-Nong Khai-Udon Thani-Nakhon Ratchasima-Laem Chabang link to NSEC.

- This addresses another major omission in the GMS economic corridors, i.e., Vientiane being not part of any of the economic corridors.

- The Vientiane-Nong Khai-Bangkok route is the main trade route between the Lao PDR and Thailand, with Laem Chabang Port acting as a gateway port to landlocked Lao PDR. On the other hand, the route from Vientiane to Boten is the main land route between the PRC and the Lao PDR.

- The addition of this route in NSEC will expand the coverage of economic corridors in the Lao PDR and recognize its important location at the center of the subregion.

Include a Bangkok and Ha Noi link in NSEC using the Bangkok-Nakhon Ratchasima-Udon Thani-Sakon Nakhon-Nakhon PhanomThakhek-Na Phao-Chalo (via Route No. 12)-Vung Anh-Vinh-Ha Noi route. ${ }^{24}$

- This will provide the Lao PDR with the shortest route to the maritime gateway at Vung Anh in Viet Nam, and support the Lao PDR's connectivity strategy for its transformation from a landlocked to a land-linked country.

- This will connect two important capitals and economic centers in the GMS-Bangkok and $\mathrm{Ha} \mathrm{Noi}^{25}$ - and will serve as another link to the PRC (Nanning).

- This is in accordance with the agreement reached during the Lao-Thai Transport Ministerial Meeting in July 2015 in Bangkok, in which Thailand agreed to consider the Lao PDR's request for assistance in upgrading National Road 12, with the Lao PDR in turn concurring with the inclusion of this route in Protocol 1 of the Cross-Border Transport Facilitation Agreement (CBTA).

- This route will shorten the distance between Bangkok and Ha Noi by at least 150 kilometers compared with the route through EWEC. It will open up new opportunities in response to market needs. ${ }^{26}$

- Development of this route is one of the initiatives in the Ayeyarwady-Chao Phrya-Mekong Economic Cooperation Strategy Plan of Action, 2016-2018. ${ }^{27}$

Include a link between Vientiane and Ha Noi using the Paksan-Nam Phao-Cau Treo-Vinh route with an extension to Vung Anh.

- This route connects Vientiane and Ha Noi through Vinh, and reinforces the role of Vientiane in GMS economic corridor development.

- This route also provides access to the sea from Vientiane to the new seaport in Vung Anh in Viet Nam. The Lao PDR and Viet Nam have signed a memorandum of understanding for the Lao PDR's use of Vung Anh Port as one of the country's gateway to the sea.

- This route is parallel to the priority expressway alignment linking Vientiane to $\mathrm{Ha} \mathrm{Noi}$, which is currently under a preliminary survey by both Lao and Viet Nam authorities.

\section{Other Proposals}

Other suggestions have been made for inclusion of some routes either as an economic corridor or as part of the GMS corridor network. One of these is the proposal for a second EWEC connecting Thanh Hoa (Viet Nam), Luang Prabang (Lao PDR), and Sittwe and Kyaukpyu (Myanmar). As this proposed corridor requires further study and analysis, including its detailed alignment, it may be more suitably addressed in an overall review of the GMS corridor network in the GMS TSS.

24 This will require an amendment of the Attachment to Protocol 1 of the Cross Border Transport Facilitation Agreement (CBTA) and/or the trilateral memorandum of understanding among the Lao PDR, Thailand, and Viet Nam.

25 Alternative alignments in the Lao PDR and Viet Nam are discussed in B. G. Nguyen. 2012. Potential Economic Corridors between Vietnam and Lao PDR in M. Ishida ed. Emerging Economic Corridors in the Mekong Region. BRC Research Report No. 8. Bangkok Research Center.

26 Representatives of the GMS Business Council and Freight Transport Association stated in a meeting with the review team that truckers prefer to use this route to Route No. 9 when going to Ha Noi.

27 The plan of action was adopted at the Sixth Summit of Ayeyarwady-Chao Phrya-Mekong Economic Cooperation Strategy held in Nay Pyi Taw, Myanmar in June 2015 


\section{COMPLEMENTARY MEASURES AND APPROACHES}

The adoption of the proposed extension and/or realignment of East-West Economic Corridor (EWEC), North-South Economic Corridor (NSEC), and Southern Economic Corridor (SEC) will add more routes to the existing ones, so the question of investment prioritization arises. To address this issue, a classification system should be adopted, which would specify the focus of interventions depending on the level of a particular corridor. For example, certain corridors may have many missing links and/or poor road conditions, in which case the main objective is to achieve physical connectivity by improving transport infrastructure. In corridors where physical connectivity has been substantially established, the focus would be on transport and trade facilitation (TTF), urban development, enterprise development, and investment promotion. Although the transition from one level to another is not clear-cut, this classification system can guide in identifying which interventions should be prioritized in particular corridors. A proposed classification system and corresponding focus of interventions is shown in Table 3.

\section{TABLE 3: Proposed Levels of Economic Corridors and Corresponding Focus of Interventions}

\begin{tabular}{c|l|l} 
Level & \multicolumn{1}{|c}{ Characteristic/s } & \multicolumn{1}{|c}{ Priority Focus of Interventions } \\
\hline 1 & $\begin{array}{l}\text { Cross-border connection/s established but there are many important } \\
\text { sections and "missing links" that require substantial improvement }\end{array}$ & $\begin{array}{l}\text { Physical connectivity-improvement of transport infrastructure in } \\
\text { the corridor }\end{array}$ \\
\hline 2 & $\begin{array}{l}\text { Cross-border connection/s established; a few sections require } \\
\text { improvement }\end{array}$ & $\begin{array}{l}\text { Physical connectivity-improvement of transport infrastructure in } \\
\text { the corridor, improvement of cross-border facilities }\end{array}$ \\
\hline 4 & $\begin{array}{l}\text { Transport infrastructure nearing completion along the full length } \\
\text { of the corridor } \\
\text { of the corridor; TTF and other measures in progress }\end{array}$ & $\begin{array}{l}\text { Improvement of cross-border facilities, transport and trade facilitation } \\
\text { (TTF), facilitation of logistics services }\end{array}$ \\
\hline 5 & $\begin{array}{l}\text { Transport infrastructure completed along the full length of the } \\
\text { corridor; major sections functioning as trade and transit corridor; } \\
\text { able to attract investments along and around it }\end{array}$ & $\begin{array}{l}\text { Continuation of TTF, facilitation of logistics services, border and corridor } \\
\text { towns development, investment promotion and enterprise development, } \\
\text { improvement of access to and from adjacent areas, multimodal transport } \\
\text { development }\end{array}$ \\
\hline trade and investment, multimodal integration and interoperability, \\
expanding urban-rural linkages along and around the corridor
\end{tabular}

Source: ADB Study Team.

The names of the routes in NSEC and SEC and those in the Greater Mekong Subregion (GMS) Transport Sector Strategy (TSS) have caused some misunderstanding, if not confusion, because some corridors refer to the same routes but are called differently. For example, the North-South Corridor in the GMS TSS is equivalent to the Western Subcorridor of NSEC. Only the east-west corridor and the southern coastal corridor are consistently identified in both the GMS TSS and strategies and action plans. Table 4 shows the current names of the nine corridors in the GMS TSS and those of the corresponding sections in EWEC, NSEC, and SEC.

It is proposed that the names EWEC, NSEC, and SEC be retained, as these are already well-known to GMS stakeholders. However, it would be necessary to be clear about which specific route or subcorridor under NSEC and SEC is being referred to, as there would be eight routes or subcorridors in NSEC after reconfiguration, and four in SEC. In this regard, it is suggested that the subcorridors in NSEC and SEC be renamed using the main nodal points along their routes with corresponding acronyms NSEC-1, NSEC-2, SEC-1, SEC-2, etc. For example, the Western Subcorridor in NSEC would be called "Kunming-Chiang RaiBangkok via the Lao PDR or Myanmar Subcorridor (NSEC-1)," and so on. Table 5 shows the proposed changes in the names of the subcorridors in NSEC and SEC. 
TABLE 4: Present Names of the Greater Mekong Subregion Corridors in the Transport Sector Strategy and Strategies and Action Plans for East-West Economic Corridor, North-South Economic Corridor, and Southern Economic Corridor

\begin{tabular}{l|l}
\begin{tabular}{l|l} 
In Transport Sector Strategy \\
1. North-South Corridor
\end{tabular} & NSEC: Western Subcorridor \\
\hline 2. Northern Corridor & NSEC: Eastern Subcorridor (Nanning to Fangcheng section only) \\
\hline 3. Eastern Corridor & NSEC: Central Subcorridor (Kunming-Ha Noi-Hai Phong and Nanning-Ha Noi only) \\
\hline 4. East-West Corridor & EWEC \\
\hline 5. Southern Corridor & SEC: Central and Northern Subcorridors \\
\hline 6. Southern Coastal Corridor & SEC: Southern Coastal Subcorridor \\
\hline 7. Central Corridor & SEC: Intercorridor Link (Sihanoukville up to the junction with EWEC at Mukdahan-Savannakhet) \\
\hline 8. Western Corridor & Not included \\
\hline 9. Northeastern Corridor & Not included \\
\hline
\end{tabular}

EWEC = East-West Economic Corridor, Lao PDR = Lao People's Democratic Republic, NSEC = North-South Economic Corridor, SEC = Southern Economic Corridor.

a ADB. 2007. GMS Transport Sector Strategy 2006-2015: Coast to Coast and Mountain to Sea: Toward Integrated Mekong Transport Systems. Manila.

a ADB. 2010. Strategy and Action Plan for the Greater Mekong Subregion East-West Economic Corridor. Manila; ADB. 2010. Toward Sustainable and Balanced Development: Strategy and Action Plan for the Greater Mekong Subregion North-South Economic Corridor. Manila; ADB. 2010. Sharing Growth and Prosperity: Strategy and Action Plan for the Greater Mekong Subregion Southern Economic Corridor. Manila.

Source: ADB Study Team.

TABLE 5: Proposed Names of North-South Economic Corridor and Southern Economic Corridor Subcorridors

\begin{tabular}{|c|c|}
\hline Present Name & Proposed Name \\
\hline \multicolumn{2}{|r|}{ NSEC } \\
\hline Western Subcorridor & Kunming-Chiang Rai-Bangkok via the Lao PDR or Myanmar Subcorridor (NSEC-1) \\
\hline No equivalent; not included in NSEC & $\begin{array}{l}\text { Kunming-Boten-Oudomxay-Luang Prabang-Vang Vieng-Vientiane-Nong Khai-Udon Thani-Nakhon } \\
\text { Ratchasima-Laem Chabang Subcorridor (NSEC-2) }\end{array}$ \\
\hline Central Subcorridor & Kunming-Ha Noi-Hai Phong Subcorridor (NSEC-3) \\
\hline Eastern Subcorridor & Nanning-Ha Noi Subcorridor (NSEC-4) \\
\hline No equivalent; not included in NSEC & Kunming-Muse-Mandalay-Yangon-Thilawa Subcorridor (NSEC-5) \\
\hline No equivalent; not included in NSEC & Mandalay-Tamu Subcorridor (NSEC-6) \\
\hline No equivalent; not included in NSEC & $\begin{array}{l}\text { Laem Chabang-Bangkok-Nakhon Ratchasima-Udon Thani-Nakhon Phanom-Thakhek-Na Phao-Vuong Ang- } \\
\text { Ha Noi Subcorridor (NSEC-7) }\end{array}$ \\
\hline No equivalent, not included in NSEC & Vientiane-Paksan-Vinh-Ha Noi Subcorridor (NSEC-8) \\
\hline \multicolumn{2}{|r|}{ EWEC } \\
\hline East-West Economic Corridor & East-West Economic Corridor \\
\hline \multicolumn{2}{|r|}{ SEC } \\
\hline Central Subcorridor & Dawei-Bangkok-Phnom Penh-Ho Chi Minh City-Vung Tau Subcorridor (SEC-1) \\
\hline Northern Subcorridor & Bangkok-Siem Reap-Stung Treng-Pleiku-Quy Nhon Subcorridor (SEC-2) \\
\hline Southern Coastal Subcorridor & Bangkok-Trat-Kampot-Ha Tien-Nam Can Subcorridor (SEC-3) \\
\hline Intercorridor Link & Sihanoukville-Phnom Penh-Stung Treng-Pakse-Savannakhet Subcorridor (SEC-4) \\
\hline
\end{tabular}

EWEC = East-West Economic Corridor, Lao PDR = Lao People's Democratic Republic, NSEC = North-South Economic Corridor, SEC = Southern Economic Corridor. Source: ADB Study Team. 
Table 6 demonstrates how the proposed classification system can be applied to the renamed economic corridors. For each corridor, the table shows the corresponding level and some information on the status of sections within the corridors.

No corridor has reached level 5 (Table 3), while four of the seven NSEC routes are rated level 4. Only one of the four SEC routes is at level 4. The lowest ranked is the Mandalay-Tamu Corridor, which requires substantial improvement in physical connectivity along the corridor.

For monitoring and evaluating progress in transforming transport corridors into economic corridors, a grading system could be adopted using various indicators (in absolute and percentage change terms over time), which may include

- value and volume of cross-border trade in key border crossings along the corridor,

- cross-border traffic (cargo and passenger) in key border crossings along the corridor,

- number of tourist arrivals in tourist attractions along or around the corridor,

- value of investments made along and around the corridor, and

- operations of special economic zones or industrial parks along and around the corridor.

The indicators could then be weighted and consolidated as a single rating for a corridor. This monitoring and evaluation system can be built on the 2015 baseline survey of traffic and trade volumes and values at selected border crossings and relevant data from other sources.

Table 6: Sample Application of the Proposed Classification of the Greater Mekong Subregion Economic Corridors

\begin{tabular}{|c|c|c|}
\hline Corridor & Level & Remarks \\
\hline \multicolumn{3}{|c|}{ NSEC } \\
\hline NSEC-1: Kunming-Chiang Rai-Bangkok via the Lao PDR or Myanmar Corridor & 4 & $\begin{array}{l}\text { Transport infrastructure on the route via the Lao PDR is } \\
\text { substantially completed. }\end{array}$ \\
\hline $\begin{array}{l}\text { NSEC-2: Kunming-Boten-Oudomxay-Luang Prabang-Vang Vieng-Vientiane- } \\
\text { Nong Khai-Udon Thani-Nakhon Ratchasima-Laem Chabang Corridor }\end{array}$ & $3-4$ & Boten-Luang Prabang-Vientiane (3), Vientiane-Bangkok (4) \\
\hline NSEC-3: Kunming-Ha Noi-Hai Phong Corridor & 4 & Transport infrastructure is substantially completed. \\
\hline NSEC-4: Nanning-Ha Noi Corridor & 4 & Transport infrastructure is substantially completed. \\
\hline NSEC-5: Kunming-Muse-Mandalay-Yangon-Thilawa Corridor & $2-3$ & $\begin{array}{l}\text { Road sections in the Myanmar component require } \\
\text { improvement. }\end{array}$ \\
\hline NSEC-6: Mandalay-Tamu Corridor & 1 & $\begin{array}{l}\text { Road section from Mandalay to Tamu requires substantial } \\
\text { improvement. }\end{array}$ \\
\hline $\begin{array}{l}\text { NSEC-7: Laem Chabang-Bangkok-Nakhon Ratchasima-Udon Thani-Nakhon } \\
\text { Phanom-Thakhek-Na Phao-Vuong Ang-Ha Noi Corridor }\end{array}$ & $2-3$ & $\begin{array}{l}\text { Road sections in the Lao PDR and some sections in Viet Nam } \\
\text { require improvement. }\end{array}$ \\
\hline NSEC-8: Vientiane-Paksan-Vinh-Ha Noi Corridor & $2-3$ & $\begin{array}{l}\text { Some road sections in the Lao PDR and Viet Nam require } \\
\text { improvement. }\end{array}$ \\
\hline \multicolumn{3}{|c|}{ EWEC } \\
\hline EWEC & 4 & Transport infrastructure is substantially completed. \\
\hline \multicolumn{3}{|c|}{ SEC } \\
\hline SEC-1: Dawei-Bangkok-Phnom Penh-Ho Chi Minh City-Vung Tau Corridor & 4 & $\begin{array}{l}\text { Road section from the Thai-Myanmar border to Dawei requires } \\
\text { improvement. }\end{array}$ \\
\hline SEC-2: Bangkok-Siem Reap-Stung Treng-Pleiku-Quy Nhon Corridor & 2 & $\begin{array}{l}\text { Road section in Cambodia from Siem Reap to the border } \\
\text { between Cambodia and Viet Nam requires improvement. }\end{array}$ \\
\hline SEC-3: Bangkok-Trat-Kampot-Ha Tien-Nam Can Corridor & 2 & Road sections in Cambodia and Viet Nam require improvement. \\
\hline SEC-4: Sihanoukville-Phnom Penh-Stung Treng-Pakse-Savannakhet Corridor & 2 & $\begin{array}{l}\text { Road sections from Stung Treng to Pakse and Savannakhet } \\
\text { require improvement. }\end{array}$ \\
\hline
\end{tabular}

EWEC = East-West Economic Corridor, Lao PDR = Lao People's Democratic Republic, NSEC = North-South Economic Corridor, SEC = Southern Economic Corridor. Source: ADB Study Team. 


\section{Changes in the Configuration of Economic Corridors}

The following changes in the configuration of the Greater Mekong Subregion (GMS) economic corridors are recommended based on the foregoing discussion on the realignment and/or extension of the economic corridors:

(i) Include an extension at the western end of the East-West Economic Corridor (EWEC) to Yangon-Thilawa using the Myawaddy-Kawkareik-Eindu-Hpa-An-Thaton-Kyaikto-Payagi-Bago-Yangon-Thilawa route, with a possible extension to Pathein.

(ii) Include the Kunming-Dali-Ruili-Muse-Mandalay-Nay Pyi Taw-Yangon route in the North-South Economic Corridor (NSEC).

(iii) Add an extension to the Kunming-Dali-Ruili-Muse-Mandalay-Nay Pyi Taw-Yangon route to link Mandalay to Tamu at the border with India, using the Mandalay-Kalewa-Tamu route via Monywa or Shwebo.

(iv) Add the Boten-Oudomxay-Luang Prabang-Vang Vieng-Vientiane-Nong Khai-Udon Thani-Nakhon RatchasimaLaem Chabang route to NSEC.

(v) Include a Bangkok and Ha Noi link in NSEC using the Bangkok-Nakhon Ratchasima-Udon Thani-Sakon NakhonNakhon Phanom-Thakhek-Na Phao-Chalo (via Route No. 12)-Vung Anh-Vinh-Ha Noi route.

(vi) Include a link between Vientiane and Ha Noi using the Paksan-Nam Phao-Cau Treo-Vinh route with an extension to Vung Anh.

Figure 7 shows the new configuration of EWEC, NSEC, and Southern Economic Corridor (SEC) based on these recommendations.

\section{Adopting Classification System and Clarifying the Names of Routes under the Economic Corridors}

It is also recommended that a classification system (Table 3) be adopted to help guide the prioritization of investments and other interventions in EWEC, NSEC, and SEC. An assessment of the state of development of the economic corridor routes, especially the new ones, can help in the preparation of such classification system. The names EWEC, NSEC, and SEC are proposed to be retained. However, the specific routes under NSEC and SEC are proposed to be named using the nodal points along their respective routes (Table 5) to avoid misunderstanding on which particular subcorridor in NSEC and SEC is being referred to.

\section{Network Approach in Greater Mekong Subregion Economic Corridor Development}

As the GMS moves to the next stage of economic corridor development, it is timely to consider shifting from an approach that focuses on each economic corridor separately to one that views the corridors as part of a network of economic corridors interacting with each other. From a practical standpoint, the various routes in EWEC, NSEC, and SEC should not be seen independently of each other, because ideally one should be able to travel on a section of SEC and then move to a section of EWEC and NSEC, e.g., from Phnom Penh along SEC to Bangkok and Tak along NSEC and to Yangon along EWEC. 


\section{Figure 7: New Configuration of East-West Economic Corridor, North-South Economic Corridor, and Southern Economic Corridor}

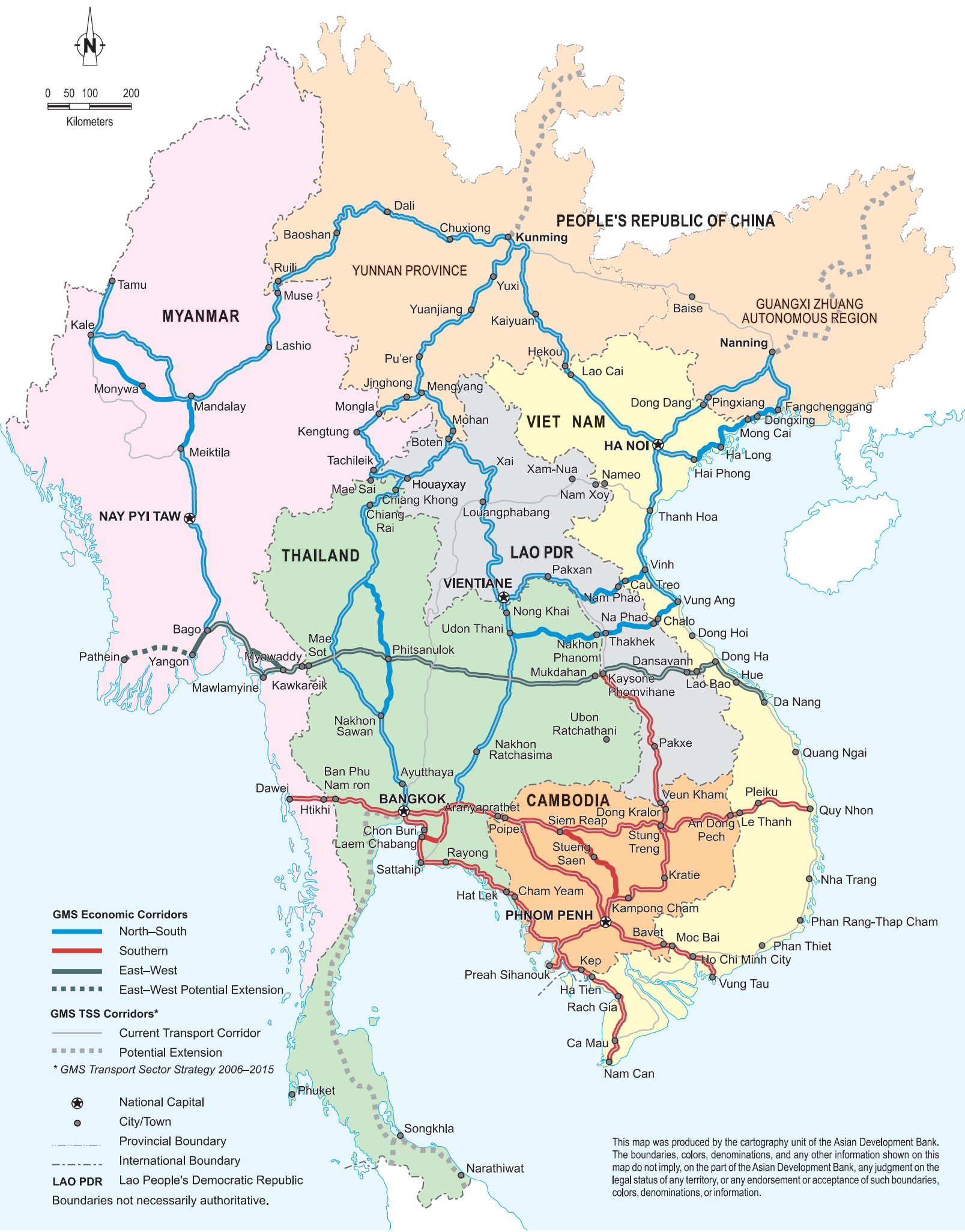

GMS = Greater Mekong Subregion TSS $=$ Transport Sector Strategy

Source: ADB Study Team. 
Travel from one end of a corridor to its other end is also highly unlikely. Accordingly, it would be beneficial to deem EWEC, NSEC, and SEC as part of an economic corridor network that allows sufficient flexibility on the routes to be taken subject to reasonable prerequisites and standards. Given the imperative for the development of railway and other modes of transport, including ports and inland waterways, the concept of a network of economic corridors may be more conducive to the development of a GMS multimodal transport system.

\section{Process of Greater Mekong Subregion Economic Corridor Development}

During the country consultations held for the review, several concerns were raised regarding the process of GMS economic corridor development, which is at the center of the GMS Program and a unique feature of cooperation in the subregion. More efforts are needed to facilitate the transformation of transport corridors into economic corridors and maximize the benefits from this initiative. In particular, the following needs require special consideration:

- accelerating and creating a momentum for the implementation of the Cross-Border Transport Facilitation Agreement and broader transport and trade facilitation measures, given that all countries have now ratified the Cross-Border Transport Facilitation Agreement;

- extending the benefits of economic corridor development to as many areas as possible through the development of feeder roads and national networks that are effectively connected to GMS economic corridors; and

- addressing unmitigated migration from vulnerable GMS economies like Cambodia and the Lao People's Democratic Republic by expanding employment opportunities in these countries along and around economic corridors through the development of industrial clusters, special economic zones, and small and medium-sized enterprises that are linked to subregional or regional production networks and value chains. 


\section{APPENDIX 1 \\ Location of Special Economic Zones in the Greater Mekong Subregion}

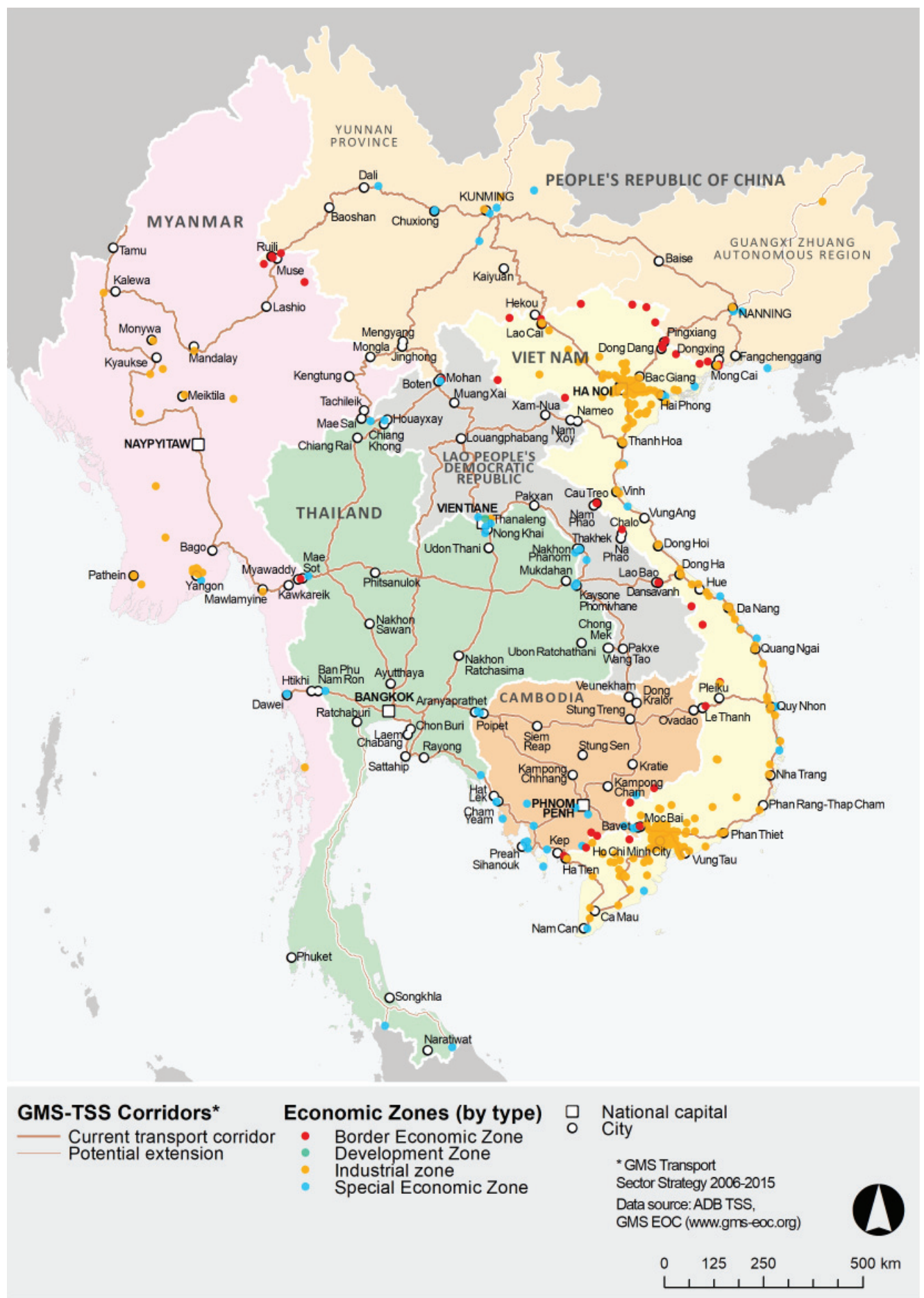

GMS = Greater Mekong Subregion, TSS = Transport Sector Strategy. Source: ADB Study Team. 


\section{APPENDIX 2}

\section{Population Distribution along the Greater Mekong Subregion Corridors}

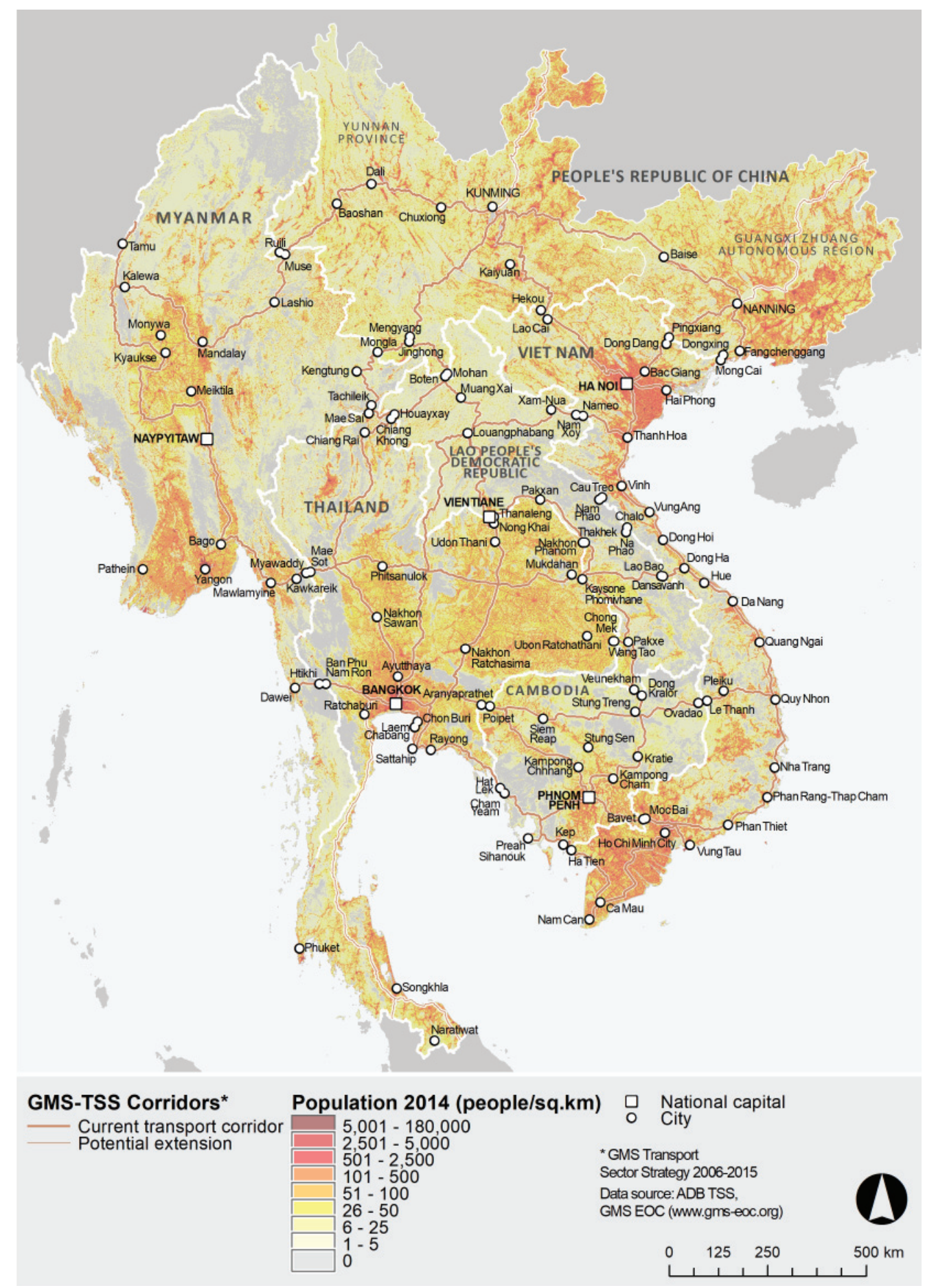

GMS = Greater Mekong Subregion, sq. km. = square kilometer, TSS = Transport Sector Strategy. Source: ADB Study Team. 


\section{APPENDIX 3}

\section{Myanmar: Exports and Imports by Trade Station}

2012-2013 Budget Year to 4 March 2015-2016 Budget Year (in million \$)

\begin{tabular}{|c|c|c|c|c|c|c|c|c|c|c|c|c|c|}
\hline \multirow[b]{2}{*}{ No. } & \multirow[b]{2}{*}{ Trading Station } & \multicolumn{3}{|c|}{ 2012-2013 } & \multicolumn{3}{|c|}{ 2013-2014 } & \multicolumn{3}{|c|}{ 2014-2015 } & \multicolumn{3}{|c|}{$\begin{array}{l}\text { 2015-2016 Budget Year } \\
\text { (until } 4 \text { March 2016) }\end{array}$} \\
\hline & & Export & Import & Total & Export & Import & Total & Export & Import & Total & Export & Import & Total \\
\hline 1 & Muse & $1,815.69$ & $1,014.17$ & $2,829.86$ & $2,210.71$ & $1,306.97$ & $3,517.68$ & $3,614.00$ & $1,704.16$ & $5,318.16$ & $3,455.95$ & $1,427.06$ & $4,883.01$ \\
\hline 2 & Lwal Jet & 21.71 & 11.06 & 32.77 & 68.84 & 7.03 & 75.87 & 63.87 & 9.30 & 73.18 & 58.62 & 11.13 & 69.75 \\
\hline 3 & Chin Shwe Haw & 57.02 & 7.36 & 64.39 & 216.28 & 30.61 & 246.90 & 358.21 & 65.64 & 423.86 & 271.29 & 48.63 & 319.92 \\
\hline 4 & Kan Pite Tee & 2.47 & 8.64 & 11.12 & 6.42 & 23.13 & 29.55 & 8.82 & 50.21 & 59.02 & 22.52 & 62.82 & 85.34 \\
\hline 5 & Kengtung & 0 & 0 & 0 & 0 & 0 & 0 & 7.39 & 5.07 & 12.46 & 6.10 & 6.90 & 13.00 \\
\hline 6 & Tachilek & 11.84 & 27.89 & 39.74 & 13.54 & 58.96 & 72.50 & 8.44 & 93.52 & 101.96 & 9.18 & 73.15 & 82.33 \\
\hline 7 & Myawaddy & 55.84 & 88.96 & 144.80 & 49.12 & 222.38 & 271.50 & 32.87 & 424.03 & 456.90 & 39.18 & 602.61 & 641.79 \\
\hline 8 & Kawthaung & 29.61 & 49.31 & 78.91 & 39.05 & 109.17 & 148.22 & 35.85 & 79.85 & 115.70 & 39.88 & 78.05 & 117.94 \\
\hline 9 & Myeik & 127.28 & 27.82 & 155.10 & 113.18 & 41.24 & 154.42 & 106.42 & 39.57 & 146.00 & 129.40 & 26.71 & 156.12 \\
\hline 10 & $\mathrm{Na} \mathrm{Bu} \mathrm{Le/Htee} \mathrm{Khee}$ & 0 & 0 & 0 & 0.15 & 1.34 & 1.49 & 0.31 & 3.91 & 4.22 & 1.36 & 11.11 & 12.48 \\
\hline 11 & Maw Taung & 0 & 0 & 0 & 0.09 & 1.90 & 1.99 & 0.08 & 0.58 & 0.66 & 0.36 & 2.08 & 2.44 \\
\hline 12 & Sittwe & 3.66 & 0.18 & 3.83 & 10.35 & 5.71 & 16.06 & 6.43 & 0.08 & 6.51 & 5.04 & 0.98 & 6.01 \\
\hline 13 & Maungdaw & 0.00 & 0.00 & 0.00 & 5.48 & 1.29 & 6.77 & 7.67 & 0.11 & 7.77 & 4.68 & 0.06 & 4.74 \\
\hline 14 & Tamu & 7.40 & 1.74 & 9.14 & 15.82 & 9.83 & 25.65 & 33.05 & 12.57 & 45.62 & 29.20 & 10.22 & 39.42 \\
\hline \multirow[t]{2}{*}{15} & Reed & 1.46 & 1.43 & 2.88 & 12.15 & 7.34 & 19.49 & 9.56 & 5.54 & 15.10 & 18.30 & 5.34 & 23.64 \\
\hline & Total & $2,133.97$ & $1,238.56$ & $3,372.53$ & $2,761.19$ & $1,826.90$ & $4,588.09$ & $4,292.98$ & $2,494.14$ & $6,787.12$ & $4,091.08$ & $2,366.85$ & $6,457.92$ \\
\hline
\end{tabular}

Source: Government of Myanmar, Ministry of Commerce, Department of Trade. 


\section{Review of Configuration of the Greater Mekong Subregion Economic Corridors}

The economic corridor approach was adopted by the Greater Mekong Subregion (GMS) countries in 1998 to help accelerate subregional development. The development of economic corridors links production, trade, and infrastructure within a specific geographic area. The review of these corridors was conducted to take into account the opening up of Myanmar and ensure that there is a close match between corridor routes and trade flows; GMS capitals and major urban centers are connected to each other; and the corridors are linked with maritime gateways. The review came up with recommendations for possible extension and/or realignment of the corridors, and adoption of a classification system for corridor development. The GMS Ministers endorsed the recommendations of the study at the 21st GMS Ministerial Conference in Thailand in 2016.

\section{About the Asian Development Bank}

ADB's vision is an Asia and Pacific region free of poverty. Its mission is to help its developing member countries reduce poverty and improve the quality of life of their people. Despite the region's many successes, it remains home to a large share of the world's poor. $A D B$ is committed to reducing poverty through inclusive economic growth, environmentally sustainable growth, and regional integration.

Based in Manila, ADB is owned by 67 members, including 48 from the region. Its main instruments for helping its developing member countries are policy dialogue, loans, equity investments, guarantees, grants, and technical assistance.

\section{About the Greater Mekong Subregion Economic Cooperation Program}

The Greater Mekong Subregion (GMS) is made up of Cambodia, the People's Republic of China (specifically Yunnan Province and Guangxi Zhuang Autonomous Region), the Lao People's Democratic Republic, Myanmar, Thailand, and Viet Nam. In 1992, with assistance from the Asian Development Bank and building on their shared histories and cultures, the six countries of the GMS launched a subregional economic cooperation program - the GMS Program - to enhance economic relations initially covering nine priority sectors: agriculture, energy, environment, human resource development, investment, telecommunications, tourism, transport infrastructure, and transport and trade facilitation.

$\mathrm{ADB}$

\section{ASIAN DEVELOPMENT BANK}

6 ADB Avenue, Mandaluyong City 1550 Metro Manila, Philippines www.adb.org 